\title{
Bacteriocins: An Overview of Antimicrobial, Toxicity, and Biosafety Assessment by in vivo Models
}

\author{
Diego Francisco Benítez-Chao ${ }^{1,2 t}$, Angel León-Buitimea ${ }^{1,2+}$, \\ Jordy Alexis Lerma-Escalera ${ }^{1,2}$ and José Rubén Morones-Ramírez ${ }^{1,2 *}$
}

${ }^{1}$ Facultad de Ciencias Químicas, Universidad Autónoma de Nuevo León, San Nicolás de los Garza, Mexico, ${ }^{2}$ Centro de Investigación en Biotecnología y Nanotecnología, Facultad de Ciencias Químicas, Parque de Investigación e Innovación Tecnológica, Universidad Autónoma de Nuevo León, Apodaca, Mexico

\section{OPEN ACCESS}

Edited by:

Adler Ray Dillman,

University of California, Riverside,

United States

Reviewed by:

Piyush Baindara,

University of Missouri, United States

Fliss Ismail,

Laval University, Canada

Takeshi Zendo,

Kyushu University, Japan

*Correspondence: José Rubén Morones-Ramírez jose.moronesrmr@uanl.edu.mx

${ }^{\dagger}$ These authors have contributed equally to this work

Specialty section:

This article was submitted to Antimicrobials, Resistance

and Chemotherapy,

a section of the journal

Frontiers in Microbiology

Received: 18 November 2020 Accepted: 08 March 2021

Published: 15 April 2021

Citation:

Benitez-Chao DF,

León-Buitimea A, Lerma-Escalera JA and Morones-Ramírez JR (2021)

Bacteriocins: An Overview of Antimicrobial, Toxicity, and Biosafety

Assessment by in vivo Models.

Front. Microbiol. 12:630695.

doi: 10.3389/fmicb.2021.630695
The world is facing a significant increase in infections caused by drug-resistant infectious agents. In response, various strategies have been recently explored to treat them, including the development of bacteriocins. Bacteriocins are a group of antimicrobial peptides produced by bacteria, capable of controlling clinically relevant susceptible and drug-resistant bacteria. Bacteriocins have been studied to be able to modify and improve their physicochemical properties, pharmacological effects, and biosafety. This manuscript focuses on the research being developed on the biosafety of bacteriocins, which is a topic that has not been addressed extensively in previous reviews. This work discusses the studies that have tested the effect of bacteriocins against pathogens and assess their toxicity using in vivo models, including murine and other alternative animal models. Thus, this work concludes the urgency to increase and advance the in vivo models that both assess the efficacy of bacteriocins as antimicrobial agents and evaluate possible toxicity and side effects, which are key factors to determine their success as potential therapeutic agents in the fight against infections caused by multidrug-resistant microorganisms.

Keywords: bacteriocins, antibiotics, antimicrobial resistance, antibacterial peptide, toxicity, biosafety, in vivo model

\section{INTRODUCTION}

According to the WHO, diseases caused by multidrug-resistant (MDR) pathogens are a serious worldwide public health problem (World Health Organization, 2019c). The rapid spread of MDR pathogens have reduced the effectiveness of common antibiotics (Gupta and Datta, 2019). Therefore, there is a particular need for the development of new antimicrobial agents, specifically those directed against MDR bacteria (Fair and Tor, 2014). Bacteriocins represent the most important group of antimicrobial peptides with applications in human health (Marshall and Arenas, 2003). The ability of bacteriocins to kill or inhibit relevant pathogenic bacteria (including MDR pathogens) in vitro has been well documented (Cui et al., 2012; Gabrielsen et al., 2014; Perez et al., 2014; Newstead et al., 2020). However, the use of animal models is an important part in the 
research toward the development of new therapeutic agents. There are many animal models used for screening drugs or chemical compounds in preclinical studies (Zwierzyna and Overington, 2017). Mice are the best-known animal models for in vivo bacteriocin efficacy studies. Other animal species, less frequently used, are guinea pigs, rabbits, and hamsters (Badyal and Desai, 2014). Therefore, the present review addresses the antimicrobial effects, toxicity, and biosafety of bacteriocins in in vivo systems. The bacteriocins here included are those naturally synthesized by native or recombinant producers, those chemically synthetized or bioengineered bacteriocins, those obtained from direct application of cultures with bacteriocin-producers, and those bacteriocins produced in cell-free supernatants (CFSs). Moreover, we here discuss the toxicity and biosafety in vivo assays, in different animal models, that have been reported during the exploration of antimicrobial effects.

\section{ANTIMICROBIAL RESISTANCE: GLOBAL EMERGENCY}

The death toll caused by drug-resistant infections has been dangerously rising every year within the last two decades. According to World Health Organization (2019c), at least 700,000 people died annually around the world because of this. In Europe, deaths raised from 25,000 in 2007 (European Centre for Disease Prevention and Control, 2009) to 33,110 in 2015 (Cassini et al., 2019). Moreover, according to WHO Africa, 54,000 cases of MDR tuberculosis were detected in 42 countries, and approximately 3200 cases of extensively drug-resistant (XDR) tuberculosis were notified in eight countries from the African region from 2004 to 2011 (Ndihokubwayo et al., 2013). China, one of the most populated countries, reported that between 2005 and 2017, the range of isolated drug-resistant bacteria varied from 22,774 to 190,610 (Qu et al., 2019). During 2017 in India, a study reported that $70 \%$ of drug-resistant Gram-negative isolates corresponded to Escherichia coli, Klebsiella pneumoniae, Acinetobacter baumannii, and Pseudomonas aeruginosa (Taneja and Sharma, 2019). Regarding the United States, 23,000 deaths were counted in 2013; 6 years later, in 2019, numbers increased to 35,000 deaths associated with antibiotic-resistant infections (Frieden, 2013). In particular, Mexico has a dramatic lack of information and epidemiological surveillance for antibiotic resistance (Amabile-Cuevas, 2010). Recently, a 6-month study assessed the resistance rates of several bacterial pathogens in 47 Mexican centers. They included almost 23,000 strains, and their results showed that the most common drug-resistant strains were E. coli, Klebsiella sp., Enterobacter sp., P. aeruginosa, Acinetobacter sp., vancomycin-resistant Enterococcus faecium, and methicillin-resistant Staphylococcus aureus (MRSA) (GarzaGonzález et al., 2019). According to the WHO, if severe actions are not taken by 2050, it is estimated that 10 million people will die annually around the world due to diseases caused by MDR pathogens. This situation may cause a severe economic impact with consequences similar to the 2009 Global Financial Crisis (World Health Organization, 2019c).

\section{CURRENT TREATMENTS FOR BACTERIAL INFECTIONS}

Since their discovery in 1928, antibiotics have effectively controlled bacterial infections (Podolsky, 2018). The current treatments for bacterial infections include bactericidal or bacteriostatic agents from different classes of antibiotics. The most common classes of drugs are penicillins, cephalosporins, quinolones, macrolides, tetracyclines, glycopeptides, and monobactams, among others (Taylor et al., 2002).

Within the last two decades, a variety of antibiotics have been approved to treat infections caused by Gram-positive and Gram-negative bacteria. Novel antibiotics against Grampositive bacteria include $\beta$-lactams (ceftaroline and ceftobiprole), glycopeptides (dalbavancin, oritavancin, and telavancin), oxazolidinones (tedizolid phosphate), quinolones (besifloxacin, delafloxacin, and ozenoxacin), and tetracyclines (omadacycline). The main advantage of the previously mentioned antibiotics is their efficiency in the treatment of bacterial infections caused by MDR strains (Koulenti et al., 2019b). Recently approved treatments to combat MDR Gram-negative bacteria include antibiotic combinations of $\beta$-lactam $/ \beta$-lactamase inhibitors (ceftolozane/tazobactam, ceftazidime/avibactam, and meropenem/vaborbactam), and aminoglycosides (plazomicin) combined with tetracyclines (eravacycline) (Koulenti et al., 2019a). Nonetheless, misuse and overuse of these combinatorial treatments have contributed to further development of antibiotic resistance (Malik and Bhattacharyya, 2019).

The rapid spread of MDR and XDR bacteria in both hospitals and community settings has reduced the effectiveness of antibiotics (Gupta and Datta, 2019). One of the main concerns regarding antibiotic resistance is that some bacteria have become resistant to almost all currently available antibiotics. Therefore, these bacteria represent a severe public health problem worldwide. Of particular interest are the following strains: MRSA, vancomycin-intermediate and -resistant; E. faecium, vancomycin-resistant; Enterobacteriaceae, carbapenemresistant, extended-spectrum beta-lactamase (ESBL)-producing; A. baumannii, carbapenem-resistant; and $P$. aeruginosa, carbapenem-resistant (World Health Organization, 2017).

Preventing and controlling the spread of antibiotic resistance is necessary to invest in research and development of new agents with therapeutic potential to treat bacterial infections. According to data from the WHO, there is an arsenal of 50 antimicrobial agents and their combinations in clinical development. Thirtytwo are antibiotics active against the WHO priority pathogens, ten are biological agents, two are classified as innovative agents, and two are active against MDR Gram-negative bacteria (World Health Organization, 2019a).

\section{BACTERIOCINS AS ALTERNATIVE ANTIMICROBIAL AGENTS}

There is a particular need for new antimicrobial agents, specifically those directed against antibiotic-resistant bacteria (Fair and Tor, 2014). Defensins and bacteriocins represent 
the most important groups of antimicrobial peptides with applications in human health (Marshall and Arenas, 2003). Defensins are small cysteine-rich (forming three to six disulfide bonds) cationic antimicrobial peptides ubiquitous among eukaryotes that form an essential element of innate immunity. They consist of two analogous superfamilies and an extensive convergent evolution is the source of their similarities (Shafee et al., 2016). Bacteriocins are ribosomally synthesized peptides secreted by a variety of bacteria for the purpose of killing other bacteria. Thereby, whereas defensins are important components of the host immune response against infection in eukaryotes (Arnett and Seveau, 2011), bacteriocins participate in removing microbial competition in prokaryotes (Cotter et al., 2013).

The way to classify defensins and bacteriocins has been based on their biochemical (net charge) and/or structural features (linear/circular/amino acid composition) and there is a current search for common patterns that might help to distinguish them (Tossi and Sandri, 2002; Zasloff, 2002). To determine whether all molecules are homologous or have independently evolved similar features, the best evidence lies in the structure. The antimicrobial peptides can be differentiated from their overall three-dimensional structure and the spacing of half-cystine residues involved in intrachain disulfide bonds (Marshall and Arenas, 2003). To date, only two bacteriocins (bactofencin and laterosporulin) have been expressed as defensin-like bacteriocins. Bactofencin is a disulfide bond-containing bacteriocin with highly conserved cysteine residues and structurally related to eukaryotic defensins due to their highly cationic nature (O'Shea et al., 2013; O'Connor et al., 2018). The laterosporulin has been previously identified from a Brevibacillus laterosporus strain GI-9 and contain disulfide bonds in positions homologous to eukaryotic defensins (Singh et al., 2012). The presence of disulfide connectivity suggests its similarity to $\beta$-defensins while its architectural similarity is related to $\alpha$-defensins (Singh et al., 2015). Recently, laterosporuli10, a novel defensin-like bacteriocin (class II bacteriocin) from the Brevibacillus sp. strain SKDU10, was characterized. This bacteriocin showed 57.6\% homology with laterosporulin and differences in the molecular weight and the number of cationic amino acids. It was highly efficient in killing S. aureus (Gram-positive bacteria) and the Mycobacterium tuberculosis $\mathrm{H} 37 \mathrm{Rv}$ strain when compared to laterosporulin (Baindara et al., 2017). Interestingly, Class II bacteriocins are easily manipulated by genetic engineering techniques because they do not have large post-translational modifications and it is possible to obtain variants according to the technological requirements and needs (Zheng and Sonomoto, 2018; Kumariya et al., 2019). Therefore, this technique could be useful to develop new antimicrobial peptides to be used as an alternative to common antibiotics.

As stated above, bacteriocins represent an interesting solution to reduce the development of resistance. Besides, bacteriocins are continuously evolving with high potential against clinically relevant pathogens (Piper et al., 2009; Bonhi and Imran, 2019). Bacteriocins can be easily manipulated by bioengineering techniques (Field et al., 2010). Unlikely to antibiotics, bacteriocins can be engineered to attach anywhere on the cellular outer membrane because they do not have a specific receptor (Bonhi and Imran, 2019) and they can be produced in situ by probiotics (Dobson et al., 2012; O'Shea et al., 2012). Consequently, this represents a new path in bacteriocin research that will undoubtedly lead to the development of new therapeutic strategies with highly relevant clinical applications (Chikindas et al., 2018).

\section{ANTIBACTERIAL ACTIVITY OF BACTERIOCINS IN IN VITRO STUDIES}

In vitro antimicrobial activity assays are the first step to evaluate the biological capacity of bacteriocins against clinically relevant bacterial pathogens (Ansari et al., 2018; Peng et al., 2019). However, if the conditions used in the in vitro models are not adequate to assess a specific effect, then the probabilities of success in the in vivo models will be very low (Blay et al., 2007; Umu et al., 2016). Fortunately, many bacteriocins have been successfully tested using in vitro assays against relevant bacterial pathogens (including MDR pathogens) (Cui et al., 2012; Gabrielsen et al., 2014; Perez et al., 2014; Newstead et al., 2020). Some examples include bacteriocin AS-48, which is active against reference and clinical strains of M. tuberculosis (AguilarPérez et al., 2018). Pentocin JL-1 has also been demonstrated to have antibacterial activity against Gram-positive and Gramnegative bacteria, particularly MDR S. aureus (Jiang et al., 2017). Other examples, such as the novel entianin, which has activity against MRSA (ATCC 43300) and vancomycinresistant Enterococcus faecalis (ATCC 51299) strains (Fuchs et al., 2011), and bacteriocins klebicins have been demonstrated to be active against MDR and carbapenem-resistant Klebsiella species (Denkovskienè et al., 2019). Moreover, novel enterocins DD28 and DD93 showed anti-staphylococcal activity in MRSA (Al Atya et al., 2016). It is important to mention that many current reports on the study of bacteriocins are focused on pathogens considered by WHO as a priority (World Health Organization, 2017) such as carbapenem-resistant E. coli or K. pneumoniae (Chen et al., 2019), vancomycin-resistant, and MDR E. faecium (Phumisantiphong et al., 2017).

As expected, bacteriocins have an outstanding record to kill or reduce pathogens and drug-resistant pathogens during in vitro assessments (Fuchs et al., 2011; Cui et al., 2012; Gabrielsen et al., 2014; Ishibashi et al., 2014; Al Atya et al., 2016; Jiang et al., 2017; Aguilar-Pérez et al., 2018; Ansari et al., 2018; Denkovskienė et al., 2019; Peng et al., 2019; Newstead et al., 2020). Conventionally, bacteriocins display a non-toxic behavior at in vitro assays (Cebrián et al., 2019). Thus, the promising results obtained after in vitro assays must be extrapolated into in vivo assays (KokaiKun et al., 2003). Furthermore, at this stage, internal factors of the host (pharmacokinetic parameters) should be considered (Meade et al., 2020) as well as the potential bacteriocin-induced toxicity (Gupta et al., 2014). Therefore, the use of animal models is mandatory in the development of a new therapeutic agent and the successful results obtained from these experiments are essential to close the translational gap to the clinic (Denayer et al., 2014). The description of the preclinical drug discovery and development process is shown in Figure 1. 


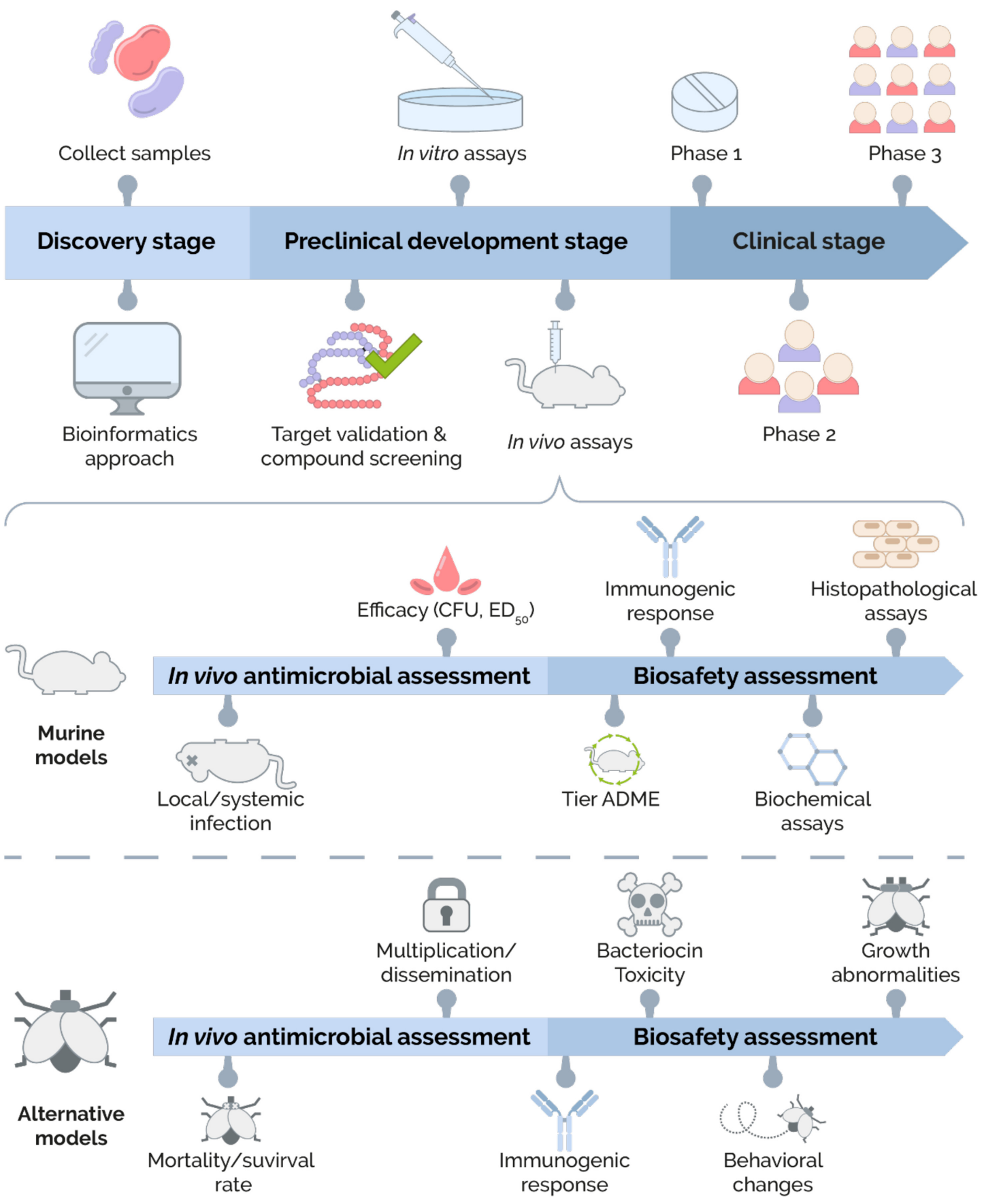

FIGURE 1 | Overview of the bacteriocin development process. The bacteriocin development process is divided into three big stages: Discovery, Preclinical development, and Clinical development. In the Discovery stage, two main approaches for bacteriocins are identified. The traditional approach consists of collecting environmental samples to isolate bacteriocin-producers. On the other hand, bacteriocins can be obtained by designing and analyzing databases using a bioinformatic approach. Next, the Preclinical development stage is divided into three subcategories: target validation and compound screening, in vitro assays, and in vivo assays. The first subcategory focuses on screening, structure-function analysis, and characterization of bacteriocins. The second subcategory's main goal is to demonstrate the antimicrobial activity and cytotoxicity effects by in vitro assays. The third subcategory includes the in vivo assays. The in vivo antimicrobial activity and biosafety assessment of bacteriocins can be carried out using murine and alternative models. The in vivo antimicrobial assessment in murine models includes the use of local and systemic infection models in rodents and the evaluation of efficacy. The biosafety assessment includes evaluating various parameters, such as pharmacokinetics profile (ADME), immunogenic response, and biochemical and histopathological analysis. On the other hand, the in vivo antimicrobial assessment in alternatives models (e.g., fruit fly, zebrafish, roundworm, greater wax moth, or brine shrimp) allows determining the mortality/survival rates and the ability of bacteriocin to block multiplication/dissemination of pathogenic agent. Biological parameters such as the immunogenic response, bacteriocin toxicity, behavioral changes, and growth abnormalities are evaluated during the biosafety evaluation. Once bacteriocin has shown to be effective and safe in in vivo models, it advances to the Clinical development stage where its dose, efficacy, and side effects are evaluated through different phases (Phases 1-3) until its approval and commercialization. 


\section{IN VIVO ASSESSMENT OF BACTERIOCINS}

There are many animal models used for screening drugs or chemical compounds in preclinical testing (pharmacological bioassays) (Zwierzyna and Overington, 2017) and specific toxicity studies (toxicological bioassays) (Creton et al., 2010). Rodents (rats and mice) are the most frequently used animal species. Other animal species, less frequently used, are guinea pigs, rabbits, and hamsters (Badyal and Desai, 2014). Invertebrate models can be used to assess many biological activities, and these include Drosophila melanogaster (fruit fly) and Caenorhabditis elegans (a nematode worm) (Badyal and Desai, 2014). Finally, zebrafish is the most used rapidly developing vertebrate, and it has proven to be an excellent model for toxicity testing (Segner et al., 2003).

\section{In vivo Assessment of Bacteriocins in Murine Models}

In terms of genomics, the strategies for cloning, gene knockout, and gene or genome modifications are very well-described. Genes are very well-conserved between mice and humans since they share $90 \%$ of their total genes, and they are also available to develop spontaneous mutations. In terms of biology, mice are small and easy to handle; they can be easily transported and raised in a laboratory. Gestation times of mice are relatively short, and a large number of offspring can be obtained for in vivo purposes (Masopust et al., 2017). Therefore, mice are the best-known animal model for in vivo bacteriocin efficacy studies.

As mentioned earlier, the ability of bacteriocins to kill or inhibit pathogenic bacteria in vitro has been well documented. Bacteriocins represent one of the most studied microbial defense systems (Cavera et al., 2015). They may facilitate the introduction of a producer into an established niche, directly inhibit the invasion of competing strains or pathogens, or modulate the composition of the microbiota and influence the host immune system (Dobson et al., 2012). Therefore, understanding that bacteriocins may function in several ways, studies involving direct correlations between in vitro efficacy and in vivo protection are needed.

To date, bacteriocins have showed a promising efficacy as antibiotic alternatives in in vivo studies. Bacteriocin application focuses in the administration at the site of the infection or susceptible areas, evading an immune response and maintaining the stability of the bacteriocin (Arthur et al., 2014). Therefore, selection of optimal bacteriocin and delivery systems has been complicated. Two factors seem to play an important role in in vivo efficacy of bacteriocins: pharmacokinetic parameters and route of administration.

First, pharmacokinetic parameters (e.g., bioavailability, stability, solubility in physiological conditions, and susceptibility to enzymatic proteolysis in bloodstream) are important determinants of the efficacy of bacteriocins (Soltani et al., 2021). Bacteriocins administered orally are exposed to the hostile environment (enzymatic and $\mathrm{pH}$ degradation) in the gastrointestinal tract; they are highly susceptible to degradation once they reach the small intestine. On the other hand, parenteral administration may offer some means of avoiding proteolytic degradation of bacteriocins in the gastrointestinal tract. Nevertheless, the efficacy may be reduced since bacteriocins will be in contact with proteases involved in hemostasis and fibrinolysis in the bloodstream (Meade et al., 2020). To reduce or avoid these problems, bacteriocins can be engineered to be less susceptible to proteolytic degradation by changing $\mathrm{D}$-amino acids (Soltani et al., 2021). Also, nanotechnology seems to be a valuable strategy to improve the physicochemical properties of the bacteriocins (Farokhzad and Langer, 2009). The nanoencapsulation [e.g., lipid-based nanoparticles (nanoliposomes and solid lipid nanoparticles), carbohydrate-based nanoparticles (chitosan/alginate and phytoglycogen nanoparticles), and conjugation with nanosized metal] of bacteriocins could protect them from enzymatic degradation, hence increasing their stability for longer periods (Fahim et al., 2016).

Second, the route of administration determines the onset and the duration of the pharmacological effect, the efficacy, and the adverse effects of drugs. The main routes of bacteriocin administration, such as intranasal (McCaughey et al., 2016a,b), intragastric (Wongsen et al., 2019), intraperitoneal (Piper et al., 2012; Sahoo et al., 2017), subcutaneous (Kers et al., 2018a,b; Pulse et al., 2019), and topical (Van Staden et al., 2016; Cebrián et al., 2019) have demonstrated excellent efficacy in murine models. However, the efficacy of the different routes of administration has not been directly compared and likely depends on the pathogen targeted (Lohans and Vederas, 2012). In the same way, in vivo toxicity testing has been conducted to identify possible adverse effects resulting from exposure to bacteriocins. As described below, many studies have been done to investigate toxicity and biosafety of bacteriocins using different type of applications, such as oral, intraperitoneal, nasal, and topical. In particular, topical application of bacteriocins has been reported to be successfully tested for skin infection with no toxicity effects. For example, the circular bacteriocin AS-48 was evaluated and the results indicated that this bacteriocin did not induce skin sensitization or cause allergic contact dermatitis (Cebrián et al., 2019). Topical formulation with two broad-spectrum bacteriocins: garvicin KS and micrococcin P1 was used in a murine skin infection model. The formulation had a significant antibacterial effect and animals showed no changes of behavior or obvious toxic effects (Ovchinnikov et al., 2020). Therefore, there is a growing interest for the study of the therapeutic properties and side effects of bacteriocins using in vivo systems (Abanoz and Kunduhoglu, 2018; Bagci et al., 2019; Iseppi et al., 2019; Lynch et al., 2019; Lajis, 2020; Meade et al., 2020).

Latest publications on in vivo assessment of bacteriocins using murine models contain as minimum parameters the measurement of the antimicrobial activity of bacteriocin on the animal model, the assessment of immunogenic response, biochemical analysis, and histopathological analysis. To support this paragraph, we have summarized some of the relevant bacteriocins with their in vivo antimicrobial (Table 1) and toxicity and biosafety (Table 2) activities in murine models over the last 20 years. In this context, we included bacteriocin studies that have 
TABLE 1 | In vivo antimicrobial assessment of bacteriocins using murine models.

\begin{tabular}{llll}
\hline Bacteriocin Producer & Target
\end{tabular}

In vivo assessment of purified or partially purified bacteriocins in murine models

Naturally synthetized bacteriocins by native producers

$$
54728
$$

Female

Nasal

Mutacin
B-Ny266

S. mutans Ny266 MSSA Strain

Mice

Intraperitoneal

Nisin, clausin, B. amyloliquefaciens (only S. aureus Xen 36

AmyA

AmyA)

Adult female Skin

nude mice

Penisin

Paenibacillus sp. Strain MRSA Strain

AS-48 E. faecalis strain UGRA10 T. cruz

$$
\text { Arequipa strain }
$$

\section{Naturally synthetized bacteriocins by heterologous producers}

Lacticin $3147 \quad$ L. lactis subsp. cremoris S. aureus Xen 29 MG1363

Pyocins S2, S5, E. coli BL21(DE3) pLysS P. aeruginosa P8 AP41, and L1

Pyocin SD2 E. coli BL21(DE3) pLysS P. aeruginosa PAO1

Male BALB/C Intraperitoneal mice

Female BALB/C Intraperitoneal mice

Female BALB/C Intraperitonea mice

Female C57/BL6 Intranasally mice

Female C57/BL6 Intranasally mice

Plantaricin E/F L. lactis NZ3900

E. coli EPEC K1.1

ddY male mice

Oral

\section{Chemically synthetized bacteriocins}

Lysostaphin Chemical Synthetized

MRSA (MBT 5040 and 12/12 Female cotton Nasa strains), MSSA (Newman ATCC 49521, ATCC 12605 and mupirocin-resistant (SA 3865 MupR)

Epidermicin NI01 Chemical Synthetized MRSA ATCC 43300 ICR mice

Female Cotton Nasa rats

In vivo assessment of bioengineered bacteriocins in murine models
$\begin{array}{lll}\text { Nisin A and } & \text { L. lactis NZ9700 and } & \text { L. monocytogenes EGDe } \\ \text { Nisin V } & \text { L. lactis } \\ & \text { NZ9800nisA:M21V } \\ \text { OG253 } & \text { S. mutans 152 producing } & \text { C. difficile UNT103-1 } \\ & \text { OG253 (Phe1lle) }\end{array}$

Female BALB/c Intraperitoneal mice

Male Golden Syrian hamsters
MRSA was absent in nasal cavity after treatment. Serum levels of IL-1 (inflammatory cytokine for innate immunity) and TNF $\alpha$ (master regulator of inflammatory response) were decreased.

Survival rate of infected mice with low and high doses of MSSA was 30 and 0\%, respectively. Survival rate in infected mice with low and high doses of MSSA treated with B-Ny266 at 1, 3, and $10 \mathrm{mg} / \mathrm{kg}$ was $100 \%$

All antimicrobial treatments (CPVA, mupirocin, nisin, clausin, and AmyA) gradually reduced the size of wound skin infections with $S$. aureus after 7 days, although clausin- and nisin-treated wounds were smaller than CPVA-treated wounds.

Penisin was significantly effective at 80 and $100 \mathrm{mg} / \mathrm{kg}$, as MRSA load decreased to Baindara et al., 2016 91 from $96 \%$ in mice, respectively. Survival rate in penisin-treated infected and untreated mice was 88 and $0 \%$ after day 4 , respectively.

$55 \%$ of organs/tissues were parasite-free in mice treated with AS- 48 at $1 \mathrm{mg} / \mathrm{kg}$ in both acute and chronic infection. 33 and $55 \%$ or organs were free of parasites after treatment with benznidazole at $100 \mathrm{mg} / \mathrm{kg}$, respectively.

Prevented the systemic spread of $S$. aureus. Microbial levels were decreased in the thoracic, abdominal cavity, and spleen but increased in liver and remained the same in thoracic,
kidney.

Mice were previously infected with P8 and treated later with S2, S5, AP41, or L1. All pyocin-treated mice survived to end point (24 $\mathrm{h}$ post infection). S5 had the highest efficacy because no P8 was recovered in any S5-treated infected mice. All the other pyocins reduce the bacterial load by 4 -log units.

Pyocin SD2-treated mice previously infected with PAO1 had no signs of illness and survived to end point (24 h post infection) and low counts of PAO1 were recovered from lungs (5 CFU/lung). Untreated infected mice were culled at $6 \mathrm{~h}$ due to severity of illness and high counts of PAO1 ( $\left.10^{5} \mathrm{CFU} / \mathrm{lung}\right)$

EPEC K1.1 was orally given to mice at $10^{8} \mathrm{CFU} / \mathrm{ml}$. Then, plantaricin $\mathrm{E}$ and $\mathrm{F}$ were given at different dosages for 7 days. Leukocyte, hematocrit (due to diarrhea), and hemoglobin levels (due to damage) were increased, and erythrocyte numbers lowered during infection. After treatment with plantaricins, mice improved their healthy. Plantaricin E at 250 and $500 \mathrm{mg} / \mathrm{kg}$ and Plantaricin F at $500 \mathrm{mg} / \mathrm{kg}$ reduced inflammatory in mice as indicator of infection.

Nasal colonization by S. aureus was eradicated at $93 \%$ in cotton rats with a single dosage of lysostaphin cream. Also, two methicilin-susceptible strains (ATCC 4952 and ATCC 12605), MRSA strain 12/12, and mupirocin-resistant SA 3865 MupR were eradicated. No antibacterial effect was observed with nisin cream at 5\% (positive control).

Untreated infected rats had mean values $3.79 \log _{10}$ CFU/nares. MRSA-infected rats treated with $\mathrm{NIO1}$ at $0.8 \%$ had mean values $0.78 \log _{10} \mathrm{CFU} /$ nares.

Bioimaging of mice was used to quantify the bioluminescent bacteria (NZ9800NISA:M21V) in organs. Nisin V exerted a better antibacterial activity in the liver and spleen than nisin $A$

Survival rate for OG253-treated challenged mice were 100\% while

vancomycin-treated mice were $33 \%$ after 21 days. All untreated challenged mice died by day 9
Kruszewska et al., 2004

Mota-Meira et al, 2005

Van Staden et al., 2016

Martín-Escolano et al. 2020

Piper et al., 2012

McCaughey et al., 2016b

McCaughey et al., 2016a

Hanny et al., 2019

Kokai-Kun et al., 2003

Campion et al., 2013

Kers et al., 2018b 


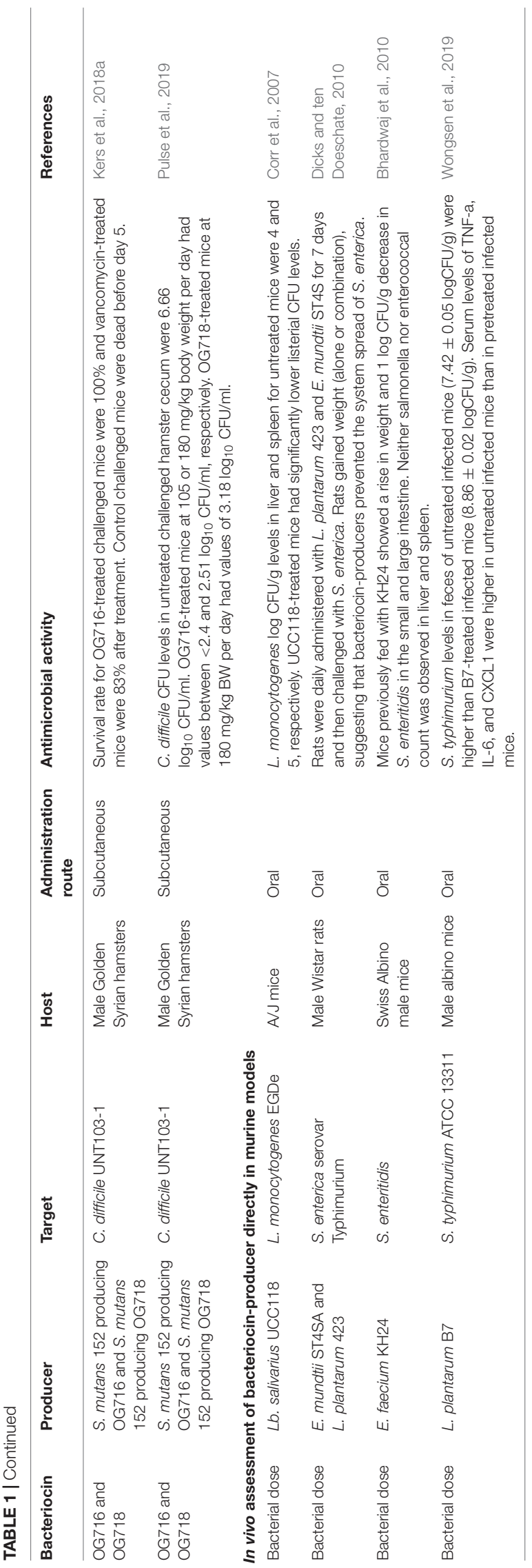

measured their effects in murine models using purified or partially purified bacteriocins (including naturally synthesized bacteriocins by native and heterologous producers and chemically synthetized bacteriocins), bioengineering bacteriocins, or the bacteriocin-producer microorganism directly in the host.

\section{In vivo Assessment of Purified or Partially Purified Bacteriocins in Murine Models}

For categorization purposes, in this section, we only include studies of bacteriocins that were applied purely or partially purified in murine models. We here consider bacteriocins that were chemically synthesized and those that were naturally synthesized from a native bacteriocin-producer or by a heterologous bacteriocin-producer.

\section{Naturally synthetized bacteriocins by native producers}

This group is characteristic since it is a straightforward system that produces bacteriocins. Native bacteriocin-producers usually excrete bacteriocins by dedicated membrane-associated ATPbinding cassette $(\mathrm{ABC})$ transporters or by the general secretion (sec) pathway of the cell (Munoz et al., 2011).

Mersacidin is a lantibiotic-type bacteriocin that was isolated and purified from Bacillus spp. HIL Y-85 54728. It has been tested in female $\mathrm{BALB} / \mathrm{cA}$ mice infected by $S$. aureus 99308. Results showed a decrease in the inflammatory response of the host (Kruszewska et al., 2004; Parameswaran and Patial, 2010; Kaneko et al., 2019). Mutacin B-Ny266 is naturally produced from Streptococcus mutans Ny266. Its antibacterial effect was proved in mice infected with methicillinsusceptible S. aureus (MSSA) strain. Moreover, no mortality was observed in mutacin B-Ny266-treated mice (Mota-Meira et al., 2005). Another bacteriocin is nisin; it has been tested along with clausin and the two components ( $\alpha$ and $\beta$-peptides) bacteriocin amyloliquecidin (AmyA) from Bacillus amyloliquefaciens against a bioluminescent strain of S. aureus Xen 36 in adult female nude mice in a wound skin infection model. Interestingly, all antimicrobial treatments reduced the bacterial load after 7 days of treatment (Van Staden et al., 2016). Penisin, from Paenibacillus sp. Strain A3, was used to effectively protect mice from a MRSA infection. Penisin-treated infected mice had a significant higher survival rate than untreated infected mice (Baindara et al., 2016). TSU4 is a bacteriocin recovered from Lactobacillus animalis TSU4. This bacteriocin was used in BALB/c mice to evaluate the acute and sub-chronic toxicity tests. Biochemical and histopathological analysis was performed. The bacteriocin demonstrated to be safe in a sub-chronic toxicity test. No antimicrobial in vivo test was performed (Sahoo et al., 2017). Finally, AS-48 bacteriocin is produced by E. faecalis strain UGRA10. The immunogenic response and biochemical and histopathological effects were analyzed in BALB/c mice (Cebrián et al., 2019). Later, its activity as antiprotozoal peptide was tested in $\mathrm{BALB} / \mathrm{c}$ mice challenged with Trypanosoma cruzi strain Arequipa (Chaga's disease etiological agent). Results demonstrated that this bacteriocin reduced the acute infection in mice (Martín-Escolano et al., 2020). 
TABLE 2 | In vivo toxicity and biosafety assessment of bacteriocins using murine models.

\begin{tabular}{|c|c|c|c|c|}
\hline Bacteriocin & Producer & Host & Toxicity and biosafety assessment & References \\
\hline \multicolumn{5}{|c|}{ In vivo assessment of purified or partially purified bacteriocins in murine models } \\
\hline \multicolumn{5}{|c|}{ Naturally synthetized bacteriocins by native producers } \\
\hline Mutacin B-Ny266 & S. mutans Ny266 & Mice & No toxicity was recorded of B-Ny266 at $10 \mathrm{mg} / \mathrm{kg}$ & Mota-Meira et al., 2005 \\
\hline $\begin{array}{l}\text { Nisin, clausin, } \\
\text { AmyA }\end{array}$ & $\begin{array}{l}\text { B. amyloliquefaciens (only } \\
\text { AmyA) }\end{array}$ & Mice & $\begin{array}{l}\text { CPVA, mupirocin, nisin, clausin, and AmyA gradually reduced the size } \\
\text { of non-infected wounds after } 7 \text { days. No toxicity assessment was } \\
\text { displayed. }\end{array}$ & Van Staden et al., 2016 \\
\hline TSU4 & L. animalis TSU4 & Male BALB/c mice & $\begin{array}{l}\text { TSU4 over } 200 \mathrm{mg} / \mathrm{kg} \text { body weight was safe enough. No significant } \\
\text { impact of bacteriocin on the kidney and liver after sub-chronic toxicity } \\
\text { test. }\end{array}$ & Sahoo et al., 2017 \\
\hline AS-48 & E. faecalis strain UGRA10 & $\begin{array}{l}\text { Female BALB/c } \\
\text { mice }\end{array}$ & $\begin{array}{l}\text { Serum biochemical measurements were performed to evaluate in vivo } \\
\text { toxicity in mice }(5 \mathrm{mg} / \mathrm{kg}) \text {. AS- } 48 \text { made changes in biochemical } \\
\text { measurements. No mice died or lost more than } 5 \% \text { body weight. After } \\
7 \text { days, mice returned to normal levels. }\end{array}$ & Cebrián et al., 2019 \\
\hline AS-48 & E. faecalis strain UGRA10 & $\begin{array}{l}\text { Female BALB/c } \\
\text { mice }\end{array}$ & $\begin{array}{l}\text { None of the treated mice died and lost more than } 10 \% \text { body weight } \\
\text { after treatment. }\end{array}$ & $\begin{array}{l}\text { Martín-Escolano et al., } \\
2020\end{array}$ \\
\hline \multicolumn{5}{|c|}{ Naturally synthetized bacteriocins by heterologous producers } \\
\hline $\begin{array}{l}\text { Pyocins S2, S5, } \\
\text { AP41, and L1 }\end{array}$ & E. coli BL21(DE3) pLysS & $\begin{array}{l}\text { Female C57/BL6 } \\
\text { mice }\end{array}$ & $\begin{array}{l}\text { Pyocins S2, S5, and L1 except AP41 were stables in the lung and do } \\
\text { not cause inflammation or tissue damage in murine lung. AP41 was } \\
\text { presumably degraded in lungs. }\end{array}$ & $\begin{array}{l}\text { McCaughey et al., } \\
2016 b\end{array}$ \\
\hline Plantaricin E/F & L. lactis NZ3900 & Male ddY mice & $\begin{array}{l}\text { Bacteriocin E or F at concentrations ranging from } 50,100,1000 \text {, and } \\
5000 \text { mg/kg body weight had no mortality in mice. Hematological and } \\
\text { biochemical parameters displayed normal levels and histopathology } \\
\text { shows normal liver and kidney cells. The leukocyte, hematocrit, and } \\
\text { hemoglobin levels in mice were improved after bacteriocin treatment; } \\
\text { also, the malondialdehyde (MDA) indicator levels were reduced. }\end{array}$ & Hanny et al., 2019 \\
\hline \multicolumn{5}{|c|}{ Chemically synthetized bacteriocins } \\
\hline Epidermicin NI01 & Chemical synthetized & Female Cotton rats & $\begin{array}{l}\text { Histology studies of the nasal cavities demonstrated mild to a marked } \\
\text { epithelial abnormality with a decreasing gradient of severity from the } \\
\text { anterior to posterior regions of the mice nasal cavities in epidermicin } \\
\text { NI01 at } 0.2 \% \text {. No cytotoxic activity, necrosis, or presence of blood was } \\
\text { noted. }\end{array}$ & Halliwell et al., 2017 \\
\hline \multicolumn{5}{|c|}{ In vivo assessment of bioengineered bacteriocins in murine models } \\
\hline OG716 and OG718 & $\begin{array}{l}\text { S. mutans } 152 \text { producing } \\
\text { OG716 and S. mutans } 152 \\
\text { producing OG718 }\end{array}$ & $\begin{array}{l}\text { Male Golden Syrian } \\
\text { hamsters }\end{array}$ & $\begin{array}{l}\text { OG716 and OG718 were administered at doses of } 180 \mathrm{mg} / \mathrm{kg} \text { body } \\
\text { weight (mg/kg BW) of hamsters challenged with C. difficile protected to } \\
\text { the rodent since survival rate was around } 80 \% \text { after } 22 \text { days of } \\
\text { treatment }\end{array}$ & Pulse et al., 2019 \\
\hline \multicolumn{5}{|c|}{ In vivo assessment of bacteriocin-producer directly in murine models } \\
\hline Bacterial dose & $\begin{array}{l}\text { E. mundtii ST4SA and } \\
\text { L. plantarum } 423\end{array}$ & Male Wistar rats & $\begin{array}{l}\text { Endotoxin levels were lowered in rats that received L. plantarum } 423 \\
\text { and E. mundtii ST4SA. No signs of splenomegaly or hepatomegaly } \\
\text { were observed in tissue samples taken from the liver and spleen, and } \\
\text { no abnormal morphological changes were observed in the epithelium of } \\
\text { the ileum and colon. }\end{array}$ & $\begin{array}{l}\text { Dicks and ten } \\
\text { Doeschate, } 2010\end{array}$ \\
\hline Bacterial dose & E. faecium $\mathrm{KH} 24$ & $\begin{array}{l}\text { Swiss Albino male } \\
\text { mice }\end{array}$ & $\begin{array}{l}\text { Total fecal enterococcal, Lactobacilli, and coliform counts (log CFU/g } \\
\text { fecal sample) were higher in mice fed with bacteriocin-producer strains } \\
\text { than non-bacteriocin-producer strains. }\end{array}$ & Bhardwaj et al., 2010 \\
\hline Bacterial dose & $\begin{array}{l}\text { L. acidophilus JCM1132 } \\
\text { (bacteriocin-producer) and } \\
\text { CCFM720 } \\
\text { (non-bacteriocin-producer) }\end{array}$ & $\begin{array}{l}\text { C57BL/6J male } \\
\text { mice }\end{array}$ & $\begin{array}{l}\text { JCM1132 strain (bacteriocin-producer) reduced the proinflammatory } \\
\text { cytokine IL-6 in mice. CCFM720 strain (non-bacteriocin-producer) } \\
\text { decreased concentration of anti-inflammatory factor IL-10. Both strains } \\
\text { showed low immunogenicity. No significant immune response was } \\
\text { recorded. CCFM720 favored the prevention of metabolic diseases. } \\
\text { JCM1132 showed weak inflammatory response in comparison to } \\
\text { CCFM720-treated mice. }\end{array}$ & Wang et al., 2020 \\
\hline
\end{tabular}

Naturally synthetized bacteriocins by heterologous producers Occasionally, the internal mechanisms of the native bacteriocinproducers to produce and excrete the bacteriocins are not enough. The objective to produce the bacteriocin in a heterologous expression system is to increase the bacteriocin production yield from native producers by facilitating the control of gene expression or increasing the production levels (Mesa-Pereira et al., 2018).

Lacticin 3147 is a two-peptide bacteriocin that is heterologousproduced in the recombinant strain Lactococcus lactis subsp. cremoris MG1363. This bacteriocin has been tested in an animal model, and the results have showed that it was able to reduce 
in vivo infection with S. aureus Xen 29 in mice (Piper et al., 2012). A very well-known example of bacteriocins from Gramnegative bacteria are pyocins, which are believed to be produced in $90 \%$ of $P$. aeruginosa strains (Michel-Briand and Baysse, 2002). The heterologous-produced pyocins S2, S5, AP41, and L1 were used to study their protective function in an acute $P$. aeruginosa lung infection in C57/BL6 mice. Among all the pyocins, S5 was the best because no pathogenic bacteria were recovered from any of the S5 treated mice. The remaining pyocins were able to reduce the bacterial count in their respective treated mice (McCaughey et al., 2016b). Shortly after, from the heterologousproduced pyocins SD1, SD2, and SD3, pyocin SD2 exerted the best performance among the other pyocins when it was tested in previously challenged C57/BL6 mice with P. aeruginosa PAO1. Treated mice were able to survive, and no signs of illness were reported (McCaughey et al., 2016a). On the other hand, plantaricin E/F are two bacteriocins (plantaricin E and F) that have been heterologously produced in L. lactis NZ3900. The in vivo effects of both plantaricins were tested independently in a murine model infection. The favorable results obtained in antibacterial and toxicological tests suggest that plantaricin E or $\mathrm{F}$ are unharmful compounds that can be considered as a strong antibiotic candidate (Hanny et al., 2019).

\section{Chemically synthetized bacteriocins}

Chemically synthesized bacteriocins are bacteriocins that were previously reported on non-modified bacteriocin-producer strains, and their antimicrobial effect have been measured on in vivo assays, but they have been synthesized chemically; some examples are lysostaphin and epidermicin NI01. First, lysostaphin was formulated on a petroleum-based cream, and it was able to eradicate $S$. aureus strain MBT 5040 in cotton rats after one single application (Kokai-Kun et al., 2003). Second, the efficacy of epidermicin NI01, for eradicating the nasal burden of MRSA strain ATCC 43300 in a cotton rat model, was carried out. Results showed that a single dose of topical epidermicin NI01 was effective in eradication of MRSA from the nares of rats (Halliwell et al., 2017).

\section{In vivo Assessment of Bioengineered Bacteriocins in Murine Models}

Bioengineered bacteriocins are a group of bacteriocins whose characteristics have been modified to upgrade their properties. These modifications consist of the generation of novel bacteriocin variants that enhance the antimicrobial activity or expand the antibacterial spectrum and anti-biofilm efficacy or improve their physicochemical properties (Field et al., 2018). Some examples of this type of bacteriocins are described below.

In vivo activity of nisin $\mathrm{A}$ and nisin $\mathrm{V}$ against Listeria monocytogenes was evaluated in mice. Nisin V (a modified version of Nisin A) was more effective than Nisin A to controlling infection (Campion et al., 2013). Mutacin 1140 (MU1140) is a lantibiotic produced by $S$. mutans. A study to identify a lead compound for the treatment of Clostridium difficile-associated diarrhea was carried out. The variant OG253 emerged as the lead compound based on superior in vivo efficacy along with an apparent lack of relapse in a hamster model of infection
(Kers et al., 2018b). In vivo testing of another MU1140-derived variant (OG716) conferred 100\% survival and no relapse at 3 weeks post $C$. difficile infection (Kers et al., 2018a). Also, the effect of OG716 is determined using an in vivo hamster model of $C$. difficile-associated disease. Results demonstrated that OG716 was an excellent compound to treat $C$. difficile enteritis in hamsters (Kers et al., 2018a).

\section{In vivo Assessment of Bacteriocin-Producer Directly in Murine Models}

Bacteriocin-producers act similarly to probiotics because both can be consumed and exert a health benefit to the host. As long as they stay in the host, they may act as colonizing peptides, killing peptides, or serve as signaling peptides (signaling other bacteria or the immune system) (Dobson et al., 2012). It has been shown that bacteriocin production by bacteriocin-producers in the gut of the host can modulate the niche competition by preventing the intestinal colonization of MDR bacteria without disturbing the natural microbiota, therefore limiting the infection (Kommineni et al., 2015; Hegarty et al., 2016).

A study demonstrated that Lactobacillus salivarius UCC118 (a sequenced and genetically tractable probiotic strain of human origin) significantly protected mice against infection with the invasive foodborne pathogen L. monocytogenes (Corr et al., 2007). In other study, rats were administered daily with Lactobacillus plantarum 423 and Enterococcus mundtii ST4SA. Then, they were challenged by infection with Salmonella enterica serovar Typhimurium. Results showed that L. plantarum 423 was more effective than E. mundtii ST4SA (Dicks and ten Doeschate, 2010). Bhardwaj et al. (2010) performed the safety assessment and evaluation of probiotic potential of bacteriocinogenic E. faecium $\mathrm{KH} 24$ strain using an in vivo model. Mice were challenged with Salmonella enteritidis MTCC 3291 and fed with E. faecium KH 24 strain. Results showed beneficial intestinal results (decreased counts of bacteria and coliform, and enhanced growth of lactobacilli) (Bhardwaj et al., 2010). The protective effects of L. plantarum B7 on diarrhea in mice induced by Salmonella typhimurium ATCC 13311 was evaluated. Results demonstrated that L. plantarum B7 could inhibit growth of S. typhimurium, decrease levels of proinflammatory cytokines, and attenuate symptoms of diarrhea induced in mice by $S$. typhimurium (Wongsen et al., 2019). Another study evaluated the effects of the bacteriocin-producing Lactobacillus acidophilus strain JCM1132 and its non-producing spontaneous mutant, L. acidophilus CCFM720, on the physiological statuses and gut microbiota of healthy mice. The results showed that both strains can have different effects on the host such as prevention of metabolic diseases and reduced inflammatory response (Wang et al., 2020).

\section{In vivo Assessment of Bacteriocins in Alternative Models}

The use of alternative models has gained great popularity among the scientific community since these models are simple, fast, and cheaper than current murine models (Apidianakis and Rahme, 2009; Jennings, 2011; OECD, 2013; Rajabi et al., 2015; Son et al., 2016; Herndon et al., 2017; Ignasiak and Maxwell, 2017; Jackson et al., 2017; Tseng et al., 2019). As we previously mentioned, some 
of these alternative models include D. melanogaster (fruit fly), Danio rerio (zebrafish embryos), C. elegans (roundworm larvae), Galleria mellonella (greater wax moth larvae), and Artemia salina (brine shrimp larvae) (Freires et al., 2017). These alternative models allow evaluating bacteriocins and their potential effects on a living organism (such as antimicrobial activity, antibiofilm effect, immunogenic response, and toxicity) (Niu et al., 2014; Thomsen et al., 2016; Hunt, 2017; Cutuli et al., 2019; Yi et al., 2019). Also, murine models and alternative models do not share the same ethical considerations since the first ones have more restrictions when it comes to conducting experiments (Baertschi and Gyger, 2011; Desalermos et al., 2011; Jennings, 2011; Hamidi et al., 2014; Simonetti et al., 2016; Tsai et al., 2016; Ignasiak and Maxwell, 2017).

A compilation of bacteriocin studies with their in vivo antimicrobial activity (Table 3) and/or toxicity and biosafety (Table 4) activity using alternative models over the last 10 years is shown below. In this context, we included studies that have measured bacteriocin effects in alternative models using purified or partially purified bacteriocins (including naturally synthetized bacteriocins by native and heterologous producers and chemically synthesized bacteriocins) or CFS with bacteriocin-like substance or with a bacteriocin-producer directly in the host.

\section{In vivo Assessment of Purified Bacteriocins in Alternative Models \\ Naturally synthetized bacteriocins by native producers}

A fruit fly model (D. melanogaster) was used to evaluate the acute toxicity of antimicrobial peptide LR14. The results showed that the peptide had a dose-dependent toxicity property (Gupta et al., 2014). Another study used the same in vivo model to evaluate the efficacy of peptide NAI-107 as treatment in MRSA infections. The authors reported that this peptide was able to rescue adult flies from fatal infection with efficacy equivalent to that of reference antibiotic (vancomycin) (Thomsen et al., 2016). The antibacterial spectrum and cytotoxicity of a bacteriocin produced by Lactobacillus lactis strain in A. salina nauplii. The antibacterial activity of bacteriocin showed a broad range against foodborne pathogens. Also, the purified bacteriocin showed cytotoxicity in brine shrimps (Rajaram et al., 2010). Son et al. (2016) identified a novel bacteriocin produced by

TABLE 3 | In vivo antimicrobial assessment of bacteriocins using alternative models.

\begin{tabular}{|c|c|c|c|c|c|}
\hline Bacteriocin & Producer & Target & $\begin{array}{l}\text { Host (Linnaeus/ } \\
\text { common name) }\end{array}$ & Antimicrobial activity & References \\
\hline
\end{tabular}

\begin{tabular}{|c|c|c|c|c|c|}
\hline \multicolumn{6}{|c|}{ Naturally synthetized bacteriocins by native producers } \\
\hline NAl-107 & ND & $\begin{array}{l}\text { S. aureus USA300 } \\
\text { (MRSA) }\end{array}$ & D. melanogaster (fruit fly) & $\begin{array}{l}\text { One dosage of NAl-107 (100 × MIC) rescued } 50-60 \% \text { of } \\
\text { MRSA-infected adult flies after } 96 \mathrm{~h} \text {. }\end{array}$ & $\begin{array}{l}\text { Thomsen et al., } \\
2016\end{array}$ \\
\hline Lichenicin 146 & $\begin{array}{l}\text { B. licheniformis } \\
\text { strain } 146\end{array}$ & S. aureus RF122 & C. elegans (roundworm) & $\begin{array}{l}\text { Survival rate of untreated infected nematodes was less than } \\
10 \% \text {, but treated nematodes had } 74 \% \text {. }\end{array}$ & Son et al., 2016 \\
\hline \multicolumn{6}{|c|}{ Naturally synthetized bacteriocins by heterologous producers } \\
\hline Pyocin S2 & E. coli & P. aeruginosa YHP14 & $\begin{array}{l}\text { G. mellonella (greater wax } \\
\text { moth) }\end{array}$ & $\begin{array}{l}\text { Untreated infected larvae died after } 12-14 \mathrm{~h} \text {. YHP14 level } \\
\text { counts in subjects were } 5 \times 10^{8} \text { and } 1 \times 10^{9} \mathrm{CFU} \text { at death } \\
\text { time. Treated larvae had } 100 \% \text { survival rate after } 72 \mathrm{~h} \text {. }\end{array}$ & $\begin{array}{l}\text { Smith et al., } \\
2012\end{array}$ \\
\hline Peocin & E. coli BL21 & A. hydrophila & D. rerio (zebrafish) & $\begin{array}{l}\text { Survival rates of infected zebrafish embryos were } 63.3 \pm 7.63 \\
\text { and } 71.67 \pm 2.88 \% \text { when } 1 \text { and } 5 \mu \mathrm{g} \text {, respectively, were } \\
\text { applied. }\end{array}$ & $\begin{array}{l}\text { Tseng et al., } \\
2019\end{array}$ \\
\hline \multicolumn{6}{|c|}{ Chemically synthetized bacteriocin } \\
\hline Epidermicin NI01 & $\begin{array}{l}\text { Chemically } \\
\text { synthetized }\end{array}$ & $\begin{array}{l}\text { MRSA and MSSA } \\
\text { ATCC } 11195\end{array}$ & $\begin{array}{l}\text { G. mellonella (greater wax } \\
\text { moth) }\end{array}$ & $\begin{array}{l}\text { Epidermicin at } 200 \mathrm{mg} / \mathrm{kg} \text { effectively increased the survival of } \\
\text { infected larvae after } 2 \mathrm{~h} \text { post infection with either MRSA or } \\
\text { MSSA. }\end{array}$ & $\begin{array}{l}\text { Gibreel and } \\
\text { Upton, } 2013\end{array}$ \\
\hline \multicolumn{6}{|c|}{ Bacteriocin-producers used directly } \\
\hline Bacterial dose & Bacillus sp. LT3 & V. campbellii & $\begin{array}{l}\text { A. franciscana (brine } \\
\text { shrimp) }\end{array}$ & $\begin{array}{l}\text { Larvae pretreated with LT3 cultures at } 10^{7} \text { cells } / \mathrm{ml} \text { exerted a } \\
\text { protective effect in larvae challenged with } V \text {. campbellii. }\end{array}$ & Niu et al., 2014 \\
\hline Bacterial dose & $\begin{array}{l}\text { L. fermentum } \\
\text { JDFM216 }\end{array}$ & $\begin{array}{l}\text { S. aureus and E. coli } \\
\text { O157:H7 }\end{array}$ & C. elegans (roundworm) & $\begin{array}{l}\text { Previously colonized worms with bacteriocin-producer } \\
\text { prolonged the lifespan of the nematodes infected against } \\
\text { S. aureus and } 0157: \mathrm{H} 7 \text {. Uncolonized infected worms died after } \\
10 \text { days. }\end{array}$ & $\begin{array}{l}\text { Park et al., } \\
2018 \\
\text { r }\end{array}$ \\
\hline AS-48 & $\begin{array}{l}\text { E. faecalis } \\
\text { UGRA10 }\end{array}$ & L. garvieae & O. mykiss (rainbow trout) & $\begin{array}{l}\text { Trout challenged with } L \text {. garvieae and UGRA10 administered in } \\
\text { diet } 30 \text { days before infection had a cumulative survival rate of } \\
50 \% \text { compared with } 0 \% \text { for control fish. }\end{array}$ & $\begin{array}{l}\text { Baños et al., } \\
2019\end{array}$ \\
\hline Bacterial dose & $\begin{array}{l}\text { P. pentosaceus } \\
\text { SL001 }\end{array}$ & A. hydrophila & $\begin{array}{l}\text { Ctenopharyngodon idella } \\
\text { (grass carp) }\end{array}$ & $\begin{array}{l}\text { Cumulative mortality rates in untreated grass (only with } \\
\text { A. hydrophila) was among } 90 \% \text {, but adapted grass was } 51.7 \% \\
\text { (SL001 plus A. hydrophila). }\end{array}$ & $\begin{array}{l}\text { Gong et al., } \\
2019\end{array}$ \\
\hline Bacterial dose & C. aquaticum & $\begin{array}{l}\text { A. hydrophila and } \\
\text { S. iniae }\end{array}$ & D. rerio (zebrafish) & $\begin{array}{l}\text { Fish previously fed with } 10^{6} \mathrm{CFU} / \mathrm{g} \text { C. aquaticum had survival } \\
\text { rates } 49.9 \pm 3.88 \% \text { when infected with } A \text {. hydrophila or } \\
53.3 \pm 7.69 \% \text { when infected with } S \text {. iniae. Unprotected fish and } \\
\text { infected with } A \text {. hydrophila or S. iniae had survival rates among } \\
28.8 \pm 7.69 \text { or } 17.7 \pm 3.85 \% \text {, respectively }\end{array}$ & Yi et al., 2019 \\
\hline
\end{tabular}


TABLE 4 | In vivo toxicity and biosafety assessment of bacteriocins using alternative models.

\begin{tabular}{|c|c|c|c|c|}
\hline Bacteriocin & Producer & $\begin{array}{l}\text { Host (Linnaeus/ } \\
\text { common name) }\end{array}$ & Toxicity and biosafety & References \\
\hline \multicolumn{5}{|c|}{ Naturally synthetized bacteriocins by native producers } \\
\hline $\begin{array}{l}\text { Unnamed } \\
\text { bacteriocin }\end{array}$ & L. lactis & A. salina (brine shrimp) & $\mathrm{LC}_{50}$ value was $21.54 \mu \mathrm{g} / \mathrm{ml}$. The immune response was not measured. & $\begin{array}{l}\text { Rajaram et al., } \\
2010\end{array}$ \\
\hline LR14 & $\begin{array}{l}\text { L. plantarum } \\
\text { LR/14 }\end{array}$ & $\begin{array}{l}\text { D. melanogaster (fruit } \\
\text { fly) }\end{array}$ & $\begin{array}{l}\mathrm{LC}_{50} \text { value was } 10 \mathrm{mg} / \mathrm{ml} .100 \% \text { lethality was observed at } 20 \mathrm{mg} / \mathrm{ml} \text {. No } \\
\text { significant mortality was reported at } 1,2 \text {, and } 5 \mathrm{mg} / \mathrm{ml} \text {. }\end{array}$ & Gupta et al., 2014 \\
\hline $\mathrm{NAl}-107$ and nisin & ND & $\begin{array}{l}\text { D. melanogaster (fruit } \\
\text { fly) }\end{array}$ & $\begin{array}{l}\text { Immunogenic response } \mathrm{NAl}-107 \text { and nisin (both alone) were measured by } \\
\text { quantifying expression of } d r s, \operatorname{cec} \mathrm{A} 1 \text {, and attB. In general, NAl-107 (100 × MIC) } \\
\text { has shown a significantly low immunogenic response than nisin }(3 \times \mathrm{MIC}) \text {. } \\
\text { Survival rate of NAl-107-treated (alone) flies was higher than nisin-treated } \\
\text { (alone) flies. Thus, NAl-107-treated flies exerted lower toxicity. }\end{array}$ & $\begin{array}{l}\text { Thomsen et al., } \\
2016\end{array}$ \\
\hline AS-48 & $\begin{array}{l}\text { E. faecalis } \\
\text { UGRA10 }\end{array}$ & D. rerio (zebrafish) & $\begin{array}{l}\text { Concentrations at } 0.64 \text { and } 1.39 \mu \mathrm{M} \text { were unharmful for } 24 \text { to } 48 \mathrm{~h} \text {. No } \\
\text { damage at } 3 \mu \mathrm{M} \text { in the first } 24 \mathrm{~h} \text {, but } 30 \% \text { of embryos were dead after } 48 \mathrm{~h} \\
\text { post-treatment. } 100 \% \text { lethality was observed at } 6.4 \text { and } 14 \mu \mathrm{M} \text { after } 24 \text { to } 48 \mathrm{~h} \\
\text { post-treatment. }\end{array}$ & Cebrián et al., 2019 \\
\hline \multicolumn{5}{|c|}{ Naturally synthetized bacteriocins by heterologous producers } \\
\hline Pyocin S2 & E. coli & $\begin{array}{l}\text { G. mellonella (greater } \\
\text { wax moth) }\end{array}$ & $\begin{array}{l}\text { Uninfected pyocin-treated moth larvae (control) had a survival rate of } 100 \% \text { with } \\
\text { pyocin at } 27 \mathrm{mg} / \mathrm{kg} \text {. }\end{array}$ & Smith et al., 2012 \\
\hline Peocin & E. coli BL21 & D. rerio (zebrafish) & $\begin{array}{l}\text { No toxicity was recorded when } 5 \mu \mathrm{g} \text { of peocin was used. However, mortality } \\
\text { increased when dosages were over } 10 \text { and } 20 \mu \mathrm{g} \text {. }\end{array}$ & Tseng et al., 2019 \\
\hline \multicolumn{5}{|c|}{ Chemically synthetized bacteriocin } \\
\hline Epidermicin NI01 & $\begin{array}{l}\text { Chemically } \\
\text { synthetized }\end{array}$ & $\begin{array}{l}\text { G. mellonella (greater } \\
\text { wax moth) }\end{array}$ & $\begin{array}{l}\text { Bacteriocin suspensions at } 200 \text { mg/kg were unharmful (neither dead nor } \\
\text { injuries) to larvae. No significant differences were found in the hemocyte density } \\
\text { (indicator larval immune system) between control and epidermicin-treated } \\
\text { larvae. }\end{array}$ & $\begin{array}{l}\text { Gibreel and Upton, } \\
2013\end{array}$ \\
\hline \multicolumn{5}{|c|}{ Cell-free supernatant with bacteriocin-like substance } \\
\hline Bacteriocin & E. hirae & A. salina (brine shrimp) & No toxicity was recorded with CFS/BLIS at 10 and 100 mg/ml. & Azab et al., 2016 \\
\hline Bacteriocin & L. curvatus P99 & $\begin{array}{l}\text { D. melanogaster (fruit } \\
\text { fly) }\end{array}$ & $\begin{array}{l}\text { Concentrations lower than or equal to } 42,109.5 \mathrm{AU} / \mathrm{ml} \text { were unharmful (survival } \\
\text { rate } 98.9 \% \text { ). Concentrations greater than } 50,000 \mathrm{AU} / \mathrm{ml} \text { were lethal (survival } \\
\text { rate less than } 50 \% \text { ) }\end{array}$ & Funck et al., 2019 \\
\hline \multicolumn{5}{|c|}{ Bacteriocin-producers used directly } \\
\hline Bacterial dose & Bacillus sp. LT3 & $\begin{array}{l}\text { A. franciscana (brine } \\
\text { shrimp) }\end{array}$ & $\begin{array}{l}\text { Innate immune response genes for melanization and coagulation (proPO and } \\
\text { tgase) were not stimulated by the presence of LT3 strain (alone) }\end{array}$ & Niu et al., 2014 \\
\hline Bacterial dose & $\begin{array}{l}\text { L. fermentum } \\
\text { JDFM216 }\end{array}$ & C. elegans (roundworm) & $\begin{array}{l}\text { Bacteriocin-producer enhances the expression of pmk-1 pathway in C. elegans } \\
\text { and, thus, stimulates the immune response and longevity of } C . \text { elegans. }\end{array}$ & Park et al., 2018 \\
\hline AS-48 & $\begin{array}{l}\text { E. faecalis } \\
\text { UGRA10 }\end{array}$ & $\begin{array}{l}\text { O. mykiss (rainbow } \\
\text { trout) }\end{array}$ & $\begin{array}{l}\text { UGRA10 was administrated in tanks filled with the fish and water for } 15 \text { days. } \\
\text { No deaths or visible signs and injuries were seen. No cytotoxicity was observed } \\
\text { in R1 cell line and trout. }\end{array}$ & Baños et al., 2019 \\
\hline Bacterial dose & $\begin{array}{l}\text { P. pentosaceus } \\
\text { SL001 }\end{array}$ & C. idella (grass carp) & $\begin{array}{l}\text { No mortality neither adverse effects were reported at high population } \\
\text { concentrations in fish diet }\end{array}$ & Gong et al., 2019 \\
\hline Bacterial dose & C. aquaticum & D. rerio (zebrafish) & $\begin{array}{l}\text { Zebrafish injected with the bacteriocin-producer increased in the expression of } \\
\text { carbohydrate metabolism-related genes in the liver and innate immune-related } \\
\text { genes were induced. }\end{array}$ & Yi et al., 2019 \\
\hline
\end{tabular}

Bacillus licheniformis strain 146 (lichenicin 146) with a high in vivo antimicrobial activity in liquid C. elegans-S. aureus assay (Son et al., 2016).

AS-48 is a bacteriocin produced by Enterococcus strains. The toxicity of this bacteriocin has been evaluated in in vivo models. In zebrafish embryos, the AS-48 was highly toxic; however, in a murine model, no toxicity was observed (Cebrián et al., 2019).

Naturally synthetized bacteriocins by heterologous producers A nonvertebrate host, the G. mellonella caterpillar, was used to evaluate the activity of pyocin S2 against $P$. aeruginosa YHP14 biofilms. Results showed a potent antibiofilm activity in vivo, representing a potential therapeutic option
(Smith et al., 2012). The antimicrobial activity of peocin, a bacteriocin produced by the probiotic Paenibacillus ehimensis NPUST1, was demonstrated in aquatic, food spoilage, clinical, and antibiotic-resistant pathogens. For example, a significant increase in survival rates was observed in peocin-treated zebrafish after Aeromonas hydrophila challenge (Tseng et al., 2019).

\section{Chemically synthetized bacteriocin}

A study reported that epidermicin NI01 had a protective effect of G. mellonella larvae from infection with clinically isolated MRSA. The authors reported that epidermicin NI01 did not induce toxicity and did not trigger the larvae immune system (Gibreel and Upton, 2013). 
In vivo assessment of CFS with bacteriocin-like substance in alternative models

The in vivo assessment of bacteriocins in alternative models has been evaluated using a CFS that contains a bacteriocin like-substance (BLIS). For example, A. salina brine shrimp showed no toxicity of CFS with BLIS from Enterococcus hirae (Azab et al., 2016). Recently, CFS from Lactobacillus curvatus P99 cultures showed no toxic effect in D. melanogaster flies (Funck et al., 2019).

\section{In vivo Assessment of Bacteriocin-Producer Directly in Alternative Models}

The evaluation of the probiotic effect of Bacillus sp. LT3 was performed in brine shrimp Artemia franciscana larvae challenged with Vibrio campbellii LMG 21363. Bacillus sp. LT3 was able to colonize the brine shrimp gastrointestinal tract and therefore increased their survival (Niu et al., 2014). A C. elegans model was used to evaluate the functionality of Lactobacillus fermentum strain JDFM216 (a novel probiotic bacterium). Interestingly, the probiotic bacterium was found to be toxic to the C. elegans host. Therefore, it has beneficial effects on longevity and immunity of C. elegans (Park et al., 2018). The effect of Pediococcus pentosaceus strain (SL001) in growth-related and immune-related genes was evaluated in grass carps. Results showed that the strain was able to enhance immunity and promoter growth of grass carps (Gong et al., 2019). A recent study evaluated the effect of probiotic Chromobacterium aquaticum on zebrafish model. Fish was challenged with A. hydrophila and Streptococcus iniae and then treated with probiotic. The probiotic-treated fish had a higher survival rate than the non-treated fish (Yi et al., 2019). Finally, the effect of $E$. faecalis UGRA10 and its bacteriocin AS-48 (multiple baths and single dose) was tested against Lactococcus garvieae in an Oncorhynchus mykiss rainbow trout fish model. Neither the strain nor its bacteriocin showed toxic effects, displaying a protective effect against L. garvieae infection (Baños et al., 2019).

The in vivo assessment models are important to evaluate bacteriocins. This review included various bacteriocins that were assessed by different in vivo models. The animal model must be

TABLE 5 | Animal models as a tool to bacteriocins analysis: strengths and limitations.

\begin{tabular}{|c|c|c|c|}
\hline Animal model & Strengths & Limitations & References \\
\hline Mice & $\begin{array}{l}\text { Physiology and genetics similarities to humans. } \\
\text { Mouse genome is very similar to human. Therefore, it is a powerful tool for } \\
\text { modeling specific genetic diseases. } \\
\text { Extremely useful for studying complex biological systems (e.g., immune, } \\
\text { endocrine nervous, cardiovascular, and skeletal systems). } \\
\text { Useful for toxicity and safety assessments of new compounds. }\end{array}$ & $\begin{array}{l}\text { Legal and ethical considerations. } \\
\text { Relatively large numbers of animals are needs for } \\
\text { research. } \\
\text { Mice models of human disease should not be } \\
\text { utilized to supplant testing in conventional animal } \\
\text { models. }\end{array}$ & $\begin{array}{l}\text { Bryda, 2013; } \\
\text { Morgan et al., } \\
\text { 2013; Perlman, } \\
\text { 2016; Andersen } \\
\text { and Winter, } 2019\end{array}$ \\
\hline
\end{tabular}

Drosophila Ideal for the study of genetics and development.

melanogaster Used to test the toxicity of chemical.

(fruit fly) $\quad 75 \%$ of the genes that cause disease in humans are also found in the fruit fly.

It is relatively straightforward to mutate (disrupt or alter).

Low cost to maintain in the laboratory.

No ethical considerations.

Caenorhabditis Most widely used and versatile model for biological and genomic research. elegans Used in longevity and senescence studies.

(roundworm Ideal for neural networks and behavior studies.

larvae) Simple anatomy, optical transparency, short lifespan.

Easy to work with; minimal nutritional and growth requirements.

Danio rerio (zebrafish embryos)

Galleria

mellonella (greater wax moth larvae)

Artemia salina (brine shrimp larvae)
$70 \%$ of human genes have at least one obvious zebrafish ortholog. Used successfully to study human disease-related genes.

Ideal model organism for studying early development. Drug safety testing and ecotoxicological screening. Its small size, accessibility, and transparency allow the analysis of thousands of live animals at single-cell resolution.

This system is cheap and fast to develop, and it can be used by small laboratories.

Used to study pathogenesis, virulence mechanisms, and immune response. Important tool for the preliminary screening of antimicrobial compounds. Rapid and reliable evaluation of the activity and toxicity of novel antimicrobial drugs.

Larvae can survive at mammalian physiological temperature $\left(37^{\circ} \mathrm{C}\right)$. Good correlation between toxicity in Galleria and that in rodents.

It is a preliminary toxicity screen.

Used in applied toxicology and ecotoxicity studies (high throughput cytotoxicity test of bioactive chemicals).

Rapid hatching and easy accessibility of nauplii in a cost-efficient way. Easy handling under laboratory conditions.
Important vertebrate-specific pathogenetic factors may be ignored.

Lack of an adaptive immune system and dramatically different drug effects when compared to human studies.

Fewer gene homologs in mammals.

Worm has two sexes (male and hermaphrodites).

Down-regulation or desensitization of target genes or proteins.

Legal and ethical considerations (some countries). They require water system to maintain them. They are not as closely related to humans as mouse is (e.g., anatomy and physiology). Genes with similar sequences often have overlapping or partially redundant functions, resulting in no or subtle defects on disruption of a single gene.

Lack of standardized procedures to use as a non-mammalian infection model.

Ignasiak and Maxwell, 2017; Toxicity experimental data (LD50) do not necessarily Cutuli et al., 2019 correlate to human values.

Lack of standardized experimental conditions (temperature, salinity, aeration, light, and $\mathrm{pH}$ ). Nunes et al., 2006; Hamidi et al., 2014; Use the same age of larvae at the start of every test. Wu, 2014; Yu and Lu, 2018 
chosen according on the expect effects for the bacteriocins. Below is summarized (Table 5) some advantages and disadvantages of murine, fruit flies, zebrafish, roundworm, greater wax moth, and brine shrimp for drug discovery trials. We included the limitations and strengths of each model as well as their scope of interest, time to reach the optimal developmental stage according to model, frequency of use in drug discovery studies, infrastructural and cost requirements for rearing, special qualifications, and ethical considerations, among others, which seem to be expected for the evaluation of new bacteriocins depending on the used model.

\section{FUTURE TRENDS IN BACTERIOCIN DEVELOPMENT AND DESIGN}

Bacteriocins represent a potential drug alternative for replacing current antibiotics to treat diseases caused by resistant bacteria. According to the body of knowledge that has been developed in the field, in general, bacteriocins can retain their in vivo antimicrobial properties in a challenged host, while at the same time, they showed a null or reduced toxic effect. According to 2019 WHO's Antibacterial Agent in Preclinical Development Book, 27 of 252 antimicrobial agents in preclinical revision status are considered as antimicrobial peptides. From the total antimicrobial peptides, 12 peptides are on lead optimization (LO) phase, 12 peptides are in Preclinical Candidate (PCC) phase and, three peptides are on CTA/IND-enabling studies (World Health Organization, 2019b). In an independent study, Theuretzbacher et al. (2020) identified the current global antibacterial pipeline and found that 135 of 407 preclinical projects from 314 private and public institutions were related to producing synthetic and natural antimicrobial peptides, natural products, and LpxC inhibitors, and most of these molecules are targeting Gramnegative bacteria. Therefore, bacteriocins may have a window of opportunity to face the drug-resistant bacteria crisis since the WHO is demanding research and development of new drugs to target the most wanted drug-resistant pathogens, many of them Gram-negative bacteria (World Health Organization, 2017).

Although it is a fact that the current literature for bacteriocins produced from Gram-negative bacteria is dominated by bacteriocins toward Gram-positive bacteria (Jamali et al., 2019), there is an acceptable amount of bacteriocins reported to have a strong activity against Gram-negative bacteria, including the pathogenic strains. For example, the S-type pyocin group from the P. aeruginosa (Ghequire and De Mot, 2014) or the microcin and colicin groups that are vastly reported for E. coli, and other examples in less quantity but not less relevant, are bacteriocins produced by K. pneumoniae, Citrobacter freundii, Shigella boydii, and Serratia marcescens (Yang et al., 2014).

The future of bacteriocins lies not only in their discovery but also in their testing for toxicity to prove their safe use in a preclinical phase as candidates for therapeutic processes. An increasing approach that can be exploited for bacteriocins is the use of alternative models to the murine model to evaluate their in vivo antimicrobial and/or toxicity effects. According to Freires et al. (2017), there is an increase in drug studies using alternative organisms to murine, since there was a rise of $909 \%$ in drug discovery from 1990 to 2015.

Finally, we have stated that bioengineering is an important tool along with the current technologies to discover new bacteriocins, since they can improve their antimicrobial activity or change their physicochemical properties. Moreover, new strategies are being introduced in the design of bacteriocins. Fields et al. (2020a) were the first to design the very first fully de novo bacteriocin by using a machine-learning approach. Fields et al. (2020b) also constructed a library of the linear peptides from the membrane-interacting region of circular bacteriocin with pore-formation dynamics by selective aminoacidic substitution. On the other hand, Acuña et al. (2012) were the first to design chimeric bacteriocins that retained the properties to kill both Gram-positive and Gram-negative bacteria. Moreover, other authors have preferred to repurpose the bacteriocins by exploiting their capability against tumor cells (Varas et al., 2020) or by exploring synergistic effects of bacteriocins while combining with renowned antibiotics (Mathur et al., 2017) or with other bacteriocins (Hanchi et al., 2017).

\section{CONCLUSION}

Bacteriocins are strong candidates to be used as future therapeutic agents. Recent studies have shown the antibacterial activity of bacteriocins using in vitro models. Nonetheless, the next step in the development of a new bacteriocin-based therapeutic agents involves the use of animal models. The antimicrobial and/or toxic effects of the bacteriocins have been studied in murine models and the most recent alternative animal models such as fruit flies, zebrafish embryos, roundworm, greater wax moth, or the brine shrimp. These results have demonstrated that bacteriocins can exert a variety of positive responses in the host such as modification of the immunogenic response, alteration of the inflammatory response, and the reduction of biochemical and histopathological parameters related with infection. However, approximately half of the bacteriocins tested in mice $(47.4 \%)$ performed antimicrobial assay, but no toxicity assays were described. On the other hand, $20 \%$ of the studies carried out in alternative models evaluated antimicrobial activity, but no toxicity was reported. These data reveal the lack of toxicity and biosafety studies of bacteriocin in vivo models, which are crucial to advance into clinical trials. Therefore, it is imperative to use in vivo models to assess the therapeutic efficacy of bacteriocins as well as their toxic effects; both successful results will lead toward clinical research phases and the development of bacteriocin-based therapeutics to treat infections caused by antimicrobial-resistant Gram-positive and Gramnegative bacteria.

\section{AUTHOR CONTRIBUTIONS}

DB-C, AL-B, and JM-R: conceptualization. DB-C, AL-B, JL-E, and JM-R: writing-original draft preparation and writingreview and editing. AL-B and JM-R: supervision. All authors contributed to the article and approved the submitted version. 


\section{FUNDING}

We would like to acknowledge Paicyt 2019-2020 and 2020-2021, Science Grants from the Universidad Autónoma de Nuevo León, and CONACyT Grants for the following: Basic science

\section{REFERENCES}

Abanoz, H. S., and Kunduhoglu, B. (2018). Antimicrobial activity of a bacteriocin produced by Enterococcus faecalis KT11 against some pathogens and antibioticresistant bacteria. Korean J. Food Sci. Anim. Resour. 38, 1064-1079. doi: 10. 5851/kosfa.2018.e40

Acuña, L., Picariello, G., Sesma, F., Morero, R. D., and Bellomio, A. (2012). A new hybrid bacteriocin, Ent35-MccV, displays antimicrobial activity against pathogenic gram-positive and gram-negative bacteria. FEBS Open Biol. 2, 12-19. doi: 10.1016/j.fob.2012.01.002

Aguilar-Pérez, C., Gracia, B., Rodrigues, L., Vitoria, A., Cebrián, R., Deboosère, N., et al. (2018). Synergy between circular bacteriocin AS-48 and ethambutol against Mycobacterium tuberculosis. Antimicrob. Agents Chemother. 62:e035918. doi: 10.1128/AAC.00359-18

Al Atya, A. K., Belguesmia, Y., Chataigne, G., Ravallec, R., Vachée, A., Szunerits, S., et al. (2016). Anti-MRSA activities of enterocins DD28 and DD93 and evidences on their role in the inhibition of biofilm formation. Front. Microbiol. 7:817. doi: $10.3389 /$ fmicb. 2016.00817

Ali, S., Champagne, D. L., Spaink, H. P., and Richardson, M. K. (2011). Zebrafish embryos and larvae: a new generation of disease models and drug screens. Birth. Defect. Res. Part C Embryo Today Rev. 93, 115-133. doi: 10.1002/bdrc.20206

Amabile-Cuevas, C. F. (2010). Antibiotic resistance in Mexico: a brief overview of the current status and its causes. J. Infect. Dev. Ctries. 4, 126-131. doi: $10.3855 /$ jidc. 427

Andersen, M. L., and Winter, L. M. F. (2019). Animal models in biological and biomedical research - experimental and ethical concerns. An. Acad. Bras. Cienc. 91:e20170238. doi: 10.1590/0001-3765201720170238

Ansari, A., Zohra, R. R., Tarar, O. M., Qader, S. A. U., and Aman, A. (2018). Screening, purification and characterization of thermostable, protease resistant Bacteriocin active against methicillin resistant Staphylococcus aureus (MRSA). BMC Microbiol. 18:192. doi: 10.1186/s12866-018-1337-y

Apidianakis, Y., and Rahme, L. G. (2009). Drosophila melanogaster as a model host for studying Pseudomonas aeruginosa infection. Nat. Protoc. 4, 1285-1294. doi: 10.1038/nprot.2009.124

Arnett, E., and Seveau, S. (2011). The multifaceted activities of mammalian defensins. Curr. Pharm. Des. 17, 4254-4269. doi: 10.2174/138161211798999348

Arthur, T. D., Cavera, V. L., and Chikindas, M. L. (2014). On bacteriocin delivery systems and potential applications. Future Microbiol. 9, 235-248. doi: 10.2217/ fmb.13.148

Azab, E. A., Elsilk, S. E., Abd El-Salam, I. S., and Tahwash, A. M. (2016). Determination of the Bacteriocin-like substances produced by Enterococcus hirae isolated from traditional Egyptian food (Koskos). Biosci. Biotechnol. Res. Asia 13, 803-813. doi: 10.13005/bbra/2100

Badyal, D. K., and Desai, C. (2014). Animal use in pharmacology education and research: the changing scenario. Indian J. Pharmacol. 46, 257-265. doi: 10.4103/ 0253-7613.132153

Baertschi, B., and Gyger, M. (2011). Ethical considerations in mouse experiments. Curr. Protoc. Mouse Biol. 1, 155-167. doi: 10.1002/9780470942390.mo100161

Bagci, U., Ozmen Togay, S., Temiz, A., and Ay, M. (2019). Probiotic characteristics of bacteriocin-producing Enterococcus faecium strains isolated from human milk and colostrum. Folia Microbiol. 64, 735-750. doi: 10.1007/s12223-01900687-2

Baindara, P., Chaudhry, V., Mittal, G., Liao, L. M., Matos, C. O., Khatri, N., et al. (2016). Characterization of the antimicrobial peptide penisin, a class Ia novel lantibiotic from Paenibacillus sp, Strain A3. Antimicrob. Agents Chemother. 60, 580-591. doi: 10.1128/AAC.01813-15

Baindara, P., Kapoor, A., Korpole, S., and Grover, V. (2017). Cysteine-rich low molecular weight antimicrobial peptides from Brevibacillus and related genera for biotechnological applications. World J. Microbiol. Biotechnol. 33:124. doi: 10.1007/s11274-017-2291-9
Grant 221332, Fronteras de la Ciencia Grant 1502, and Infraestructura Grant 279957. DB-C and JL-E acknowledge the support from Beca Nacional de Posgrado from CONACyT, and AL-B acknowledges the support from Beca de Posdoctorado Nacional.

Baños, A., Ariza, J. J., Nuñez, C., Gil-Martínez, L., García-López, J. D., MartínezBueno, M., et al. (2019). Effects of Enterococcus faecalis UGRA10 and the enterocin AS-48 against the fish pathogen Lactococcus garvieae, Studies in vitro and in vivo. Food Microbiol. 77, 69-77. doi: 10.1016/j.fm.2018. 08.002

Bhardwaj, A., Gupta, H., Kapila, S., Kaur, G., Vij, S., and Malik, R. K. (2010). Safety assessment and evaluation of probiotic potential of bacteriocinogenic Enterococcus faecium $\mathrm{KH} 24$ strain under in vitro and in vivo conditions. Int. J. Food Microbiol. 141, 156-164. doi: 10.1016/j.ijfoodmicro.2010.05.001

Blay, G., Le Lacroix, C., Zihler, A., and Fliss, I. (2007). In vitro inhibition activity of nisin A, nisin Z, pediocin PA-1 and antibiotics against common intestinal bacteria. Lett. Appl. Microbiol. 45, 252-257. doi: 10.1111/j.1472-765X.2007. 02178.x

Bonhi, K. L. R., and Imran, S. (2019). Role of bacteriocin in tackling the global problem of multi-drug resistance: an updated review. Biosci. Biotechnol. Res. Commun. 12, 601-608. doi: 10.21786/bbrc/12.3/8

Bryda, E. C. (2013). The mighty mouse: the impact of rodents on advances in biomedical research. Mo. Med. 110, 207-211.

Campion, A., Casey, P. G., Field, D., Cotter, P. D., Hill, C., and Ross, R. P. (2013). In vivo activity of Nisin $\mathrm{A}$ and $\mathrm{Nisin} \mathrm{V}$ against Listeria monocytogenes in mice. BMC Microbiol. 13:23. doi: 10.1186/1471-2180-13-23

Cassini, A., Högberg, L. D., Plachouras, D., Quattrocchi, A., Hoxha, A., Simonsen, G. S., et al. (2019). Attributable deaths and disability-adjusted life-years caused by infections with antibiotic-resistant bacteria in the EU and the European economic Area in 2015: a population-level modelling analysis. Lancet Infect. Dis. 19, 56-66. doi: 10.1016/S1473-3099(18)30605-4

Cavera, V. L., Arthur, T. D., Kashtanov, D., and Chikindas, M. L. (2015). Bacteriocins and their position in the next wave of conventional antibiotics. Int J. Antimicrob. Agents 46, 494-501. doi: 10.1016/j.ijantimicag.2015.07.011

Cebrián, R., Rodríguez-Cabezas, M. E., Martín-Escolano, R., Rubiño, S., GarridoBarros, M., Montalbán-López, M., et al. (2019). Preclinical studies of toxicity and safety of the AS-48 bacteriocin. J. Adv. Res. 20, 129-139. doi: 10.1016/j.jare. 2019.06.003

Chen, C. C., Lai, C. C., Huang, H. L., Huang, W. Y., Toh, H. S., Weng, T. C. et al. (2019). Antimicrobial activity of Lactobacillus species against carbapenemresistant Enterobacteriaceae. Front. Microbiol. 10:789. doi: 10.3389/fmicb.2019. 00789

Chikindas, M. L., Weeks, R., Drider, D., Chistyakov, V. A., and Dicks, L. M. (2018). Functions and emerging applications of bacteriocins. Curr. Opin. Biotechnol. 49, 23-28. doi: 10.1016/j.copbio.2017.07.011

Corr, S. C., Li, Y., Riedel, C. U., O’Toole, P. W., Hill, C., and Gahan, C. G. M. (2007). Bacteriocin production as a mechanism for the antiinfective activity of Lactobacillus salivarius UCC118. Proc. Natl. Acad. Sci. U.S.A. 104, 7617-7621. doi: 10.1073/pnas.0700440104

Cotter, P. D., Ross, R. P., and Hill, C. (2013). Bacteriocins - a viable alternative to antibiotics? Nat. Rev. Microbiol. 11, 95-105. doi: 10.1038/nrmicro2937

Creton, S., Dewhurst, I. C., Earl, L. K., Gehen, S. C., Guest, R. L., Hotchkiss, J. A., et al. (2010). Acute toxicity testing of chemicals-Opportunities to avoid redundant testing and use alternative approaches. Crit. Rev. Toxicol. 40, 50-83. doi: 10.3109/10408440903401511

Cui, Y., Zhang, C., Wang, Y., Shi, J., Zhang, L., Ding, Z., et al. (2012). Class IIa bacteriocins: diversity and new developments. Int. J. Mol. Sci. 13, 16668-16707. doi: 10.3390/ijms131216668

Cutuli, M. A., Petronio Petronio, G., Vergalito, F., Magnifico, I., Pietrangelo, L., Venditti, N., et al. (2019). Galleria mellonella as a consolidated in vivo model hosts: new developments in antibacterial strategies and novel drug testing. Virulence 10, 527-541. doi: 10.1080/21505594.2019.1621649

Denayer, T., Stöhrn, T., and Van Roy, M. (2014). Animal models in translational medicine: validation and prediction. New Horizons Transl. Med. 2, 5-11. doi: 10.1016/j.nhtm.2014.08.001 
Denkovskienè, E., Paškevičius, Š, Misiūnas, A., Stočkūnaite, B., Starkevič, U., Vitkauskiené, A., et al. (2019). Broad and efficient control of Klebsiella pathogens by peptidoglycan-degrading and pore-forming Bacteriocins klebicins. Sci. Rep. 9:15422. doi: 10.1038/s41598-019-51969-1

Desalermos, A., Muhammed, M., Glavis-Bloom, J., and Mylonakis, E. (2011). Using Caenorhabditis elegans for antimicrobial drug discovery. Expert Opin. Drug Discov. 6, 645-652. doi: 10.1517/17460441.2011.573781

Dicks, L. M. T., and ten Doeschate, K. (2010). Enterococcus mundtii ST4SA and Lactobacillus plantarum 423 alleviated symptoms of Salmonella infection, as determined in wistar rats challenged with Salmonella enterica serovar Typhimurium. Curr. Microbiol. 61, 184-189. doi: 10.1007/s00284-010-9594-5

Dobson, A., Cotter, P. D., Ross, R. P., and Hill, C. (2012). Bacteriocin production: a probiotic trait? Appl. Environ. Microbiol. 78, 1-6. doi: 10.1128/AEM.05576-11

European Centre for Disease Prevention and Control (2009). ECDC/EMEA Joint Technical Report: The Bacterial Challenge: Time to React. ECDC/EMEA. Available online at: https://www.ecdc.europa.eu/en/publications-data/ ecdcemea-joint-technical-report-bacterial-challenge-time-react (accessed October 8, 2020).

Fahim, H. A., Khairalla, A. S., and El-Gendy, A. O. (2016). Nanotechnology: a valuable strategy to improve bacteriocin formulations. Front. Microbiol. 7:1385. doi: $10.3389 /$ fmicb. 2016.01385

Fair, R. J., and Tor, Y. (2014). Antibiotics and bacterial resistance in the 21st century. Perspect. Medicin. Chem. 6, 25-64. doi: 10.4137/PMC.S14459

Farokhzad, O. C., and Langer, R. (2009). Impact of nanotechnology on drug delivery. ACS Nano 3, 16-20. doi: 10.1021/nn900002m

Field, D., Hill, C., Cotter, P. D., and Ross, R. P. (2010). The dawning of a "Golden era" in lantibiotic bioengineering. Mol. Microbiol. 78, 1077-1087. doi: 10.1111/ j.1365-2958.2010.07406.x

Field, D., Ross, R. P., and Hill, C. (2018). Developing bacteriocins of lactic acid bacteria into next generation biopreservatives. Curr. Opin. Food Sci. 20, 1-6. doi: $10.1016 /$ j.cofs.2018.02.004

Fields, F. R., Freed, S. D., Carothers, K. E., Hamid, M. N., Hammers, D. E., Ross, J. N., et al. (2020a). Novel antimicrobial peptide discovery using machine learning and biophysical selection of minimal bacteriocin domains. Drug Dev. Res. 81, 43-51. doi: 10.1002/ddr.21601

Fields, F. R., Manzo, G., Hind, C., Janardhanan, J., Foik, I. P., Do Carmo Silva, P., et al. (2020b). Synthetic antimicrobial peptide tuning permits membrane disruption and interpeptide synergy. ACS Pharmacol. Transl. Sci. 3, 418-424. doi: 10.1021/acsptsci.0c00001

Freires, I. A., Sardi, J., de, C. O., de Castro, R. D., and Rosalen, P. L. (2017). Alternative Animal and non-animal models for drug discovery and development: bonus or burden? Pharm. Res. 34, 681-686. doi: 10.1007/s11095016-2069-z

Frieden, T. (2013). Antibiotic resistance threats in the United States, 2013. Centers Dis. Control Prev. CS239559-B. Available online at: https://www.cdc.gov/ drugresistance/pdf/ar-threats-2013-508.pdf (accessed March 22, 2021).

Fuchs, S. W., Jaskolla, T. W., Bochmann, S., Kötter, P., Wichelhaus, T., Karas, M., et al. (2011). Entianin, a novel subtilin-like lantibiotic from Bacillus subtilis subsp. spizizenii DSM $15029^{\mathrm{T}}$ with high antimicrobial activity. Appl. Environ. Microbiol. 77, 1698-1707. doi: 10.1128/AEM.01962-10

Funck, G. D., de Lima Marques, J., da Silva Dannenberg, G., dos Santos Cruxen, C. E., Sehn, C. P., Prigol, L., et al. (2019). Characterization, toxicity, and optimization for the growth and production of bacteriocin-like substances by Lactobacillus curvatus. Probiotics Antimicrob. Proteins. 12, 91-101. doi: 10. 1007/s12602-019-09531-y

Gabrielsen, C., Brede, D. A., Nes, I. F., and Diep, D. B. (2014). Circular bacteriocins: biosynthesis and mode of action. Appl. Environ. Microbiol. 80, 6854-6862. doi: 10.1128/AEM.02284-14

Garza-González, E., Morfín-Otero, R., Mendoza-Olazarán, S., Bocanegra-Ibarias, P., Flores-Treviño, S., Rodríguez-Noriega, O., et al. (2019). A snapshot of antimicrobial resistance in Mexico. Results from 47 centers from 20 states during a six-month period. PLoS One 14:e0209865. doi: 10.1371/journal.pone. 0209865

Ghequire, M. G. K., and De Mot, R. (2014). Ribosomally encoded antibacterial proteins and peptides from Pseudomonas. FEMS Microbiol. Rev. 38, 523-568. doi: 10.1111/1574-6976.12079

Gibreel, T. M., and Upton, M. (2013). Synthetic epidermicin NI01 can protect Galleria mellonella larvae from infection with Staphylococcus aureus. J. Antimicrob. Chemother. 68, 2269-2273. doi: 10.1093/jac/dkt195
Gong, L., He, H., Li, D., Cao, L., Khan, T. A., Li, Y., et al. (2019). A new isolate of Pediococcus pentosaceus (SL001) with antibacterial activity against fish pathogens and potency in facilitating the immunity and growth performance of grass carps. Front. Microbiol. 10:1384. doi: 10.3389/fmicb.2019.0 1384

Gupta, R., Sarkar, S., and Srivastava, S. (2014). In vivo toxicity assessment of antimicrobial peptides (AMPs LR14) Derived from Lactobacillus plantarum Strain LR/14 in Drosophila melanogaster. Probiotics Antimicrob. Proteins 6, 59-67. doi: 10.1007/s12602-013-9154-y

Gupta, V., and Datta, P. (2019). Next-generation strategy for treating drug resistant bacteria: antibiotic hybrids. Indian J. Med. Res. 149, 97-106. doi: 10.4103/ijmr. IJMR_755_18

Halliwell, S., Warn, P., Sattar, A., Derrick, J. P., and Upton, M. (2017). A single dose of epidermicin NI01 is sufficient to eradicate MRSA from the nares of cotton rats. J. Antimicrob. Chemother. 72, 778-781. doi: 10.1093/jac/dkw457

Hamidi, İR., Jovanova, B., and Panovska, K. (2014). Toxicîlogical evaluation of the plant products using Brine Shrimp (Artemia salina L.) model. Maced. Pharm. Bull. 60, 9-18.

Hanchi, H., Hammami, R., Gingras, H., Kourda, R., Bergeron, M. G., Ben Hamida, J., et al. (2017). Inhibition of MRSA and of Clostridium difficile by durancin 61A: synergy with bacteriocins and antibiotics. Future Microbiol. 12, 205-212. doi: $10.2217 / \mathrm{fmb}-2016-0113$

Hanny, E. L. L., Mustopa, A. Z., Budiarti, S., Darusman, H. S., Ningrum, R. A., and Fatimah (2019). Efficacy, toxicity study and antioxidant properties of plantaricin $\mathrm{E}$ and $\mathrm{F}$ recombinants against enteropathogenic Escherichia coli K1.1 (EPEC K1.1). Mol. Biol. Rep. 46, 6501-6512. doi: 10.1007/s11033-01905096-9

Hegarty, J. W., Guinane, C. M., Ross, R. P., Hill, C., and Cotter, P. D. (2016). Bacteriocin production: a relatively unharnessed probiotic trait? F1000Research 5:2587. doi: 10.12688/f1000research.9615.1

Herndon, L. A., Wolkow, C. A., Driscoll, M., and Hall, D. H. (2017). Effects of ageing on the basic biology and anatomy of C. elegans. Healthy Age. Longev. 5, 9-39. doi: 10.1007/978-3-319-44703-2_2

Howe, K., Clark, M. D., Torroja, C. F., Torrance, J., Berthelot, C., Muffato, M., et al. (2013). The zebrafish reference genome sequence and its relationship to the human genome. Nature 496, 498-503. doi: 10.1038/nature12111

Hunt, P. R. (2017). The C. elegans model in toxicity testing. J. Appl. Toxicol. 37, 50-59. doi: $10.1002 /$ jat. 3357

Ignasiak, K., and Maxwell, A. (2017). Galleria mellonella (greater wax moth) larvae as a model for antibiotic susceptibility testing and acute toxicity trials. BMC Res. Notes 10:428. doi: 10.1186/s13104-017-2757-8

Iseppi, R., Messi, P., Camellini, S., and Sabia, C. (2019). Bacteriocin activity of Lactobacillus brevis and Lactobacillus paracasei ssp. paracasei. J. Med. Microbiol. 68, 1359-1366. doi: 10.1099/jmm.0.001045

Ishibashi, N., Himeno, K., Masuda, Y., Perez, R. H., Iwatani, S., Zendo, T., et al. (2014). Gene cluster responsible for secretion of and immunity to multiple bacteriocins, the NKR-5-3 enterocins. Appl. Environ. Microbiol. 80, 6647-6655. doi: 10.1128/AEM.02312-14

Jackson, S. J., Andrews, N., Ball, D., Bellantuono, I., Gray, J., Hachoumi, L., et al. (2017). Does age matter? The impact of rodent age on study outcomes. Lab. Anim. 51, 160-169. doi: 10.1177/0023677216653984

Jamali, H., Krylova, K., and Dozois, C. M. (2019). The 100 Top-cited scientific papers focused on the topic of bacteriocins. Int. J. Pept. Res. Ther. 25, 933-939. doi: 10.1007/s10989-018-9741-6

Jeibmann, A., and Paulus, W. (2009). Drosophila melanogaster as a model organism of brain diseases. Int. J. Mol. Sci. 10, 407-440. doi: 10.3390/ijms10020407

Jennings, B. H. (2011). Drosophila -a versatile model in biology \& medicine. Mater. Today. 14, 190-195. doi: 10.1016/S1369-7021(11)70113-4

Jiang, H., Zou, J., Cheng, H., Fang, J., and Huang, G. (2017). Purification, characterization, and mode of action of Pentocin JL-1, a novel bacteriocin isolated from Lactobacillus pentosus, against drug-resistant Staphylococcus aureus. Biomed Res. Int. 2017:7657190. doi: 10.1155/2017/7657190

Kaneko, N., Kurata, M., Yamamoto, T., Morikawa, S., and Masumoto, J. (2019). The role of interleukin-1 in general pathology. Inflamm. Regen. 39:12. doi: 10.1186/s41232-019-0101-5

Kers, J. A., DeFusco, A. W., Park, J. H., Xu, J., Pulse, M. E., Weiss, W. J., et al. (2018a). OG716: designing a fit-for-purpose lantibiotic for the treatment of Clostridium difficile infections. PLoS One 13:e0197467. doi: 10.1371/journal. pone.0197467 
Kers, J. A., Sharp, R. E., Defusco, A. W., Park, J. H., Xu, J., Pulse, M. E., et al. (2018b). Mutacin 1140 lantibiotic variants are efficacious against Clostridium difficile infection. Front. Microbiol. 9:415. doi: 10.3389/fmicb.2018.00415

Kokai-Kun, J. F., Walsh, S. M., Chanturiya, T., and Mond, J. J. (2003). Lysostaphin cream eradicates Staphylococcus aureus nasal colonization in a cotton rat model. Antimicrob. Agents Chemother. 47, 1589-1597. doi: 10.1128/AAC.47.5.15891597.2003

Kommineni, S., Bretl, D. J., Lam, V., Chakraborty, R., Hayward, M., Simpson, P., et al. (2015). Bacteriocin production augments niche competition by enterococci in the mammalian gastrointestinal tract. Nature 526, 719-735. doi: 10.1038 /nature 15524

Koulenti, D., Song, A., Ellingboe, A., Abdul-Aziz, M. H., Harris, P., Gavey, E., et al. (2019a). Infections by multidrug-resistant Gram-negative Bacteria: what's new in our arsenal and what's in the pipeline? Int. J. Antimicrob. Agents 53, 211-224. doi: 10.1016/j.ijantimicag.2018.10.011

Koulenti, D., Xu, E., Mok, I. Y. S., Song, A., Karageorgopoulos, D. E., Armaganidis, A., et al. (2019b). Novel antibiotics for multidrug-resistant gram-positive microorganisms. Microorganisms 7:270. doi: 10.3390/microorganisms7080270

Kruszewska, D., Sahl, H. G., Bierbaum, G., Pag, U., Hynes, S. O., and Ljungh, A (2004). Mersacidin eradicates methicillin-resistant Staphylococcus aureus (MRSA) in a mouse rhinitis model. J. Antimicrob. Chemother. 54, 648-653. doi: $10.1093 / \mathrm{jac} / \mathrm{dkh} 387$

Kumariya, R., Garsa, A. K., Rajput, Y. S., Sood, S. K., Akhtar, N., and Patel, S. (2019). Bacteriocins: classification, synthesis, mechanism of action and resistance development in food spoilage causing bacteria. Microb. Pathog. 128, 171-177. doi: 10.1016/j.micpath.2019.01.002

Lajis, A. F. B. (2020). Biomanufacturing process for the production of bacteriocins from Bacillaceae family. Bioresour. Bioprocess 7:8. doi: 10.1186/s40643-0200295-z

Lohans, C. T., and Vederas, J. C. (2012). Development of Class IIa Bacteriocins as therapeutic agents. Int. J. Microbiol. 2012:386410. doi: 10.1155/2012/386410

Lynch, D., O’Connor, P. M., Cotter, P. D., Hill, C., Field, D., and Begley, M. (2019). Identification and characterisation of capidermicin, a novel bacteriocin produced by Staphylococcus capitis. PLoS One 14:e0223541. doi: 10.1371/ journal.pone. 0223541

Malik, B., and Bhattacharyya, S. (2019). Antibiotic drug-resistance as a complex system driven by socio-economic growth and antibiotic misuse. Sci. Rep. 9:9788. doi: 10.1038/s41598-019-46078-y

Marshall, S. H., and Arenas, G. (2003). Antimicrobial peptides: a natural alternative to chemical antibiotics and a potential for applied biotechnology. Electron. J. Biotechnol. 6, 96-109.

Martín-Escolano, R., Cebrián, R., Maqueda, M., Romero, D., Rosales, M. J., Sánchez-Moreno, M., et al. (2020). Assessing the effectiveness of AS-48 in experimental mice models of Chagas' disease. J. Antimicrob. Chemother. 75, 1537-1545. doi: 10.1093/jac/dkaa030

Masopust, D., Sivula, C. P., and Jameson, S. C. (2017). Of mice, dirty mice, and men: using mice to understand human immunology. J. Immunol. 199, 383-388. doi: 10.4049/jimmunol.1700453

Mathur, H., Field, D., Rea, M. C., Cotter, P. D., Hill, C., and Ross, R. P. (2017). Bacteriocin-antimicrobial synergy: a medical and food perspective. Front. Microbiol. 8:1205. doi: 10.3389/fmicb.2017.01205

McCaughey, L. C., Josts, I., Grinter, R., White, P., Byron, O., Tucker, N. P., et al. (2016a). Discovery, characterization and in vivo activity of pyocin SD2, a protein antibiotic from Pseudomonas aeruginosa. Biochem. J. 473, 2345-2358. doi: 10.1042/BCJ20160470

McCaughey, L. C., Ritchie, N. D., Douce, G. R., Evans, T. J., and Walker, D. (2016b). Efficacy of species-specific protein antibiotics in a murine model of acute Pseudomonas aeruginosa lung infection. Sci. Rep. 6:30201. doi: 10.1038/ srep30201

Meade, E., Slattery, M. A., and Garvey, M. (2020). Bacteriocins, potent antimicrobial peptides and the fight against multi drug resistant species: resistance is futile? Antibiotics 9:32. doi: 10.3390/antibiotics9010032

Meneely, P. M., Dahlberg, C. L., and Rose, J. K. (2019). Working with worms: Caenorhabditis elegans as a model organism. Curr. Protoc. Essent. Lab. Tech. 19:e35. doi: 10.1002/cpet.35

Mesa-Pereira, B., Rea, M. C., Cotter, P. D., Hill, C., and Ross, R. P. (2018). Heterologous expression of biopreservative bacteriocins with a view to low cost production. Front. Microbiol. 9:1654. doi: 10.3389/fmicb.2018.01654
Michel-Briand, Y., and Baysse, C. (2002). The pyocins of Pseudomonas aeruginosa. Biochimie 84, 499-510. doi: 10.1016/S0300-9084(02)01422-0

Mirzoyan, Z., Sollazzo, M., Allocca, M., Valenza, A. M., Grifoni, D., and Bellosta, P. (2019). Drosophila melanogaster: a model organism to study cancer. Front. Genet. 10:51. doi: 10.3389/fgene.2019.00051

Morgan, S. J., Elangbam, C. S., Berens, S., Janovitz, E., Vitsky, A., Zabka, T., et al. (2013). Use of animal models of human disease for nonclinical safety assessment of novel pharmaceuticals. Toxicol. Pathol. 41, 508-518. doi: 10.1177/ 0192623312457273

Mota-Meira, M., Morency, H., and Lavoie, M. C. (2005). In vivo activity of mutacin B-Ny266. J. Antimicrob. Chemother. 56, 869-871. doi: 10.1093/jac/dki295

Munoz, M., Jaramillo, D., del Pilar Melendez, A. J., Almeciga-Diaz, C., and Sanchez, F. O. (2011). Native and heterologous production of bacteriocins from grampositive microorganisms. Recent Pat. Biotechnol. 5, 199-211. doi: 10.2174/ 187220811797579088

Ndihokubwayo, J. B., Yahaya, A. A., Desta, A. T., Ki-Zerbo, G., Odei, E. A., Keita, B., et al. (2013). Antimicrobial Resistance in the African Region: Issues, Challenges and Actions Proposed. Available online at: https:/www.afro.who.int/ sites/default/files/2017-06/amr-paper-march-2013-jbn-and-all.pdf (accessed January 29, 2021).

Newstead, L. L., Varjonen, K., Nuttall, T., and Paterson, G. K. (2020). Staphylococcal-produced bacteriocins and antimicrobial peptides: their potential as alternative treatments for Staphylococcus aureus infections. Antibiotics 9:40. doi: 10.3390/antibiotics9020040

Niu, Y., Defoirdt, T., Baruah, K., Van de Wiele, T., Dong, S., and Bossier, P. (2014). Bacillus sp. LT3 improves the survival of gnotobiotic brine shrimp (Artemia franciscana) larvae challenged with Vibrio campbellii by enhancing the innate immune response and by decreasing the activity of shrimp-associated vibrios. Vet. Microbiol. 173, 279-288. doi: 10.1016/j.vetmic.2014.08.007

Nunes, B. S., Carvalho, F. D., Guilhermino, L. M., and Van Stappen, G. (2006). Use of the genus Artemia in ecotoxicity testing. Environ. Pollut. 144, 453-462. doi: 10.1016/j.envpol.2005.12.037

O'Connor, P. M., O’ Shea, E. F., Cotter, P. D., Hill, C., and Ross, R. P. (2018). The potency of the broad spectrum bacteriocin, bactofencin A, against staphylococci is highly dependent on primary structure, N-terminal charge and disulphide formation. Sci. Rep. 8:11833. doi: 10.1038/s41598-018-30271-6

OECD (2013). “Test No. 236: Fish Embryo Acute Toxicity (FET) test," in OECD Guidelines for the Testing of Chemicals, Section 2, ed. OECD Library (Paris: OECD), 1-22. doi: 10.1787/9789264203709-en

O'Shea, E. F., Cotter, P. D., Stanton, C., Ross, R. P., and Hill, C. (2012). Production of bioactive substances by intestinal bacteria as a basis for explaining probiotic mechanisms: bacteriocins and conjugated linoleic acid. Int. J. Food Microbiol. 152, 189-205. doi: 10.1016/j.ijfoodmicro.2011.05.025

O'Shea, E. F., O'Connor, P. M., O'Sullivan, O., Cotter, P. D., Ross, R. P., and Hill, C. (2013). Bactofencin A, a New Type of Cationic Bacteriocin with Unusual Immunity. mBio 4:e0498-13. doi: 10.1128/mBio.00498-13

Ovchinnikov, K. V., Kranjec, C., Thorstensen, T., Carlsen, H., and Diep, D. B. (2020). Successful Development of Bacteriocins into Therapeutic Formulation for Treatment of MRSA Skin Infection in a Murine Model. Antimicrob. Agents Chemother. 64:e00829-20. doi: 10.1128/AAC.00829-20

Pandey, U. B., and Nichols, C. D. (2011). Human disease models in Drosophila melanogaster and the role of the fly in therapeutic drug discovery. Pharmacol. Rev. 63, 411-436. doi: 10.1124/pr.110.003293

Parameswaran, N., and Patial, S. (2010). Tumor necrosis factor-a signaling in macrophages. Crit. Rev. Eukaryot. Gene Expr. 20, 87-103. doi: 10.1615/ CritRevEukarGeneExpr.v20.i2.10

Park, M. R., Ryu, S., Maburutse, B. E., Oh, N. S., Kim, S. H., Oh, S. et al. (2018). Probiotic Lactobacillus fermentum strain JDFM216 stimulates the longevity and immune response of Caenorhabditis elegans through a nuclear hormone receptor. Sci. Rep. 8:7441. doi: 10.1038/s41598-018-25333-8

Peng, J., Long, H., Liu, W., Wu, Z., Wang, T., Zeng, Z., et al. (2019). Antibacterial mechanism of peptide Cec4 against Acinetobacter baumannii. Infect. Drug Resist. 12, 2417-2428. doi: 10.2147/IDR.S214057

Perez, R. H., Zendo, T., and Sonomoto, K. (2014). Novel bacteriocins from lactic acid bacteria (LAB): various structures and applications. Microb. Cell Fact. 13:S3. doi: 10.1186/1475-2859-13-S1-S3

Perlman, R. L. (2016). Mouse models of human disease: an evolutionary perspective. Evol. Med. Public Heal. 2016, 170-176. doi: 10.1093/emph/eow014 
Phumisantiphong, U., Siripanichgon, K., Reamtong, O., and Diraphat, P. (2017). A novel bacteriocin from Enterococcus faecalis 478 exhibits a potent activity against vancomycin-resistant Enterococci. PLoS One 12:e0186415. doi: 10.1371/ journal.pone.0186415

Piper, C., Casey, P. G., Hill, C., Cotter, P. D., and Ross, R. P. (2012). The lantibiotic lacticin 3147 prevents systemic spread of Staphylococcus aureus in a murine infection model. Int. J. Microbiol. 2012:806230. doi: 10.1155/2012/80 6230

Piper, C., Cotter, P., Ross, R., and Hill, C. (2009). Discovery of medically significant Lantibiotics. Curr. Drug Discov. Technol. 6, 1-18. doi: 10.2174/ 157016309787581075

Podolsky, S. H. (2018). The evolving response to antibiotic resistance (1945-2018). Palgrave Commun. 4:124. doi: 10.1057/s41599-018-0181-x

Pulse, M. E., Weiss, W. J., Kers, J. A., DeFusco, A. W., Park, J. H., and Handfield, M. (2019). Pharmacological, toxicological, and dose range assessment of OG716, a novel lantibiotic for the treatment of Clostridium difficile-associated infection. Antimicrob. Agents Chemother. 63:e01904-18. doi: 10.1128/AAC.01904-18

Qu, J., Huang, Y., and Lv, X. (2019). Crisis of antimicrobial resistance in china: now and the future. Front. Microbiol. 10:2240. doi: 10.3389/fmicb.2019.0 2240

Rajabi, S., Ramazani, A., Hamidi, M., and Naji, T. (2015). Artemia salina as a model organism in toxicity assessment of nanoparticles. DARU J. Pharm. Sci. 23:20. doi: 10.1186/s40199-015-0105-x

Rajaram, G., Manivasagan, P., Gunasekaran, U., Ramesh, S., Ashokkumar, S., Thilagavathi, B., et al. (2010). Isolation, identification and characterization of bacteriocin from Lactobacillus lactis and its antimicrobial and cytotoxic properties. African J. Pharm. Pharmacol. 4, 895-902. doi: 10.5897/AJPP. 9000197

Rand, M. D., Montgomery, S. L., Prince, L., and Vorojeikina, D. (2014). Developmental toxicity assays using the Drosophila model. Curr. Protoc. Toxicol. 59, 1.12.1-1.12.20. doi: 10.1002/0471140856.tx0112s59

Sahoo, T. K., Jena, P. K., Prajapati, B., Gehlot, L., Patel, A. K., and Seshadri, S. (2017). In vivo assessment of immunogenicity and toxicity of the bacteriocin TSU4 in BALB/c mice. Probiotics Antimicrob. Proteins 9, 345-354. doi: 10.1007/ s12602-016-9249-3

Schier, A. F. (2013). Zebrafish earns its stripes. Nature 496, 443-444. doi: 10.1038/ nature 12094

Segner, H., Caroll, K., Fenske, M., Janssen, C. R., Maack, G., Pascoe, D., et al. (2003). Identification of endocrine-disrupting effects in aquatic vertebrates and invertebrates: report from the European IDEA project. Ecotoxicol. Environ. Saf. 54, 302-314. doi: 10.1016/S0147-6513(02)00039-8

Shafee, T. M. A., Lay, F. T., Hulett, M. D., and Anderson, M. A. (2016). The defensins consist of two independent, convergent protein superfamilies. Mol. Biol. Evol. 33, 2345-2356. doi: 10.1093/molbev/msw106

Simonetti, R. B., Santos Marques, L., Streit, D. P. Jr., and Oberst, R. (2016). Zebrafish (Danio rerio): ethics in animal experimentation. IOSR J. Agric. Vet. Sci. Ver. 9, 2319-2372. doi: 10.9790/2380-090701106110

Singh, P. K., Chittpurna, Ashish, Sharma, V., Patil, P. B., and Korpole, S. (2012). Identification, purification and characterization of Laterosporulin, a Novel bacteriocin produced by Brevibacillus sp. Strain GI-9. PLoS One 7:e31498. doi: 10.1371/journal.pone.0031498

Singh, P. K., Solanki, V., Sharma, S., Thakur, K. G., Krishnan, B., and Korpole, S. (2015). The intramolecular disulfide-stapled structure of laterosporulin, a class IId bacteriocin, conceals a human defensin-like structural module. FEBS J. 282, 203-214. doi: 10.1111/febs.13129

Sloman, K. A., Bouyoucos, I. A., Brooks, E. J., and Sneddon, L. U. (2019). Ethical considerations in fish research. J. Fish Biol. 94, 556-577. doi: 10.1111/jfb.13946

Smith, K., Martin, L., Rinaldi, A., Rajendran, R., Ramage, G., and Walker, D. (2012). Activity of pyocin S2 against Pseudomonas aeruginosa biofilms. Antimicrob. Agents Chemother. 56, 1599-1601. doi: 10.1128/AAC.05714-11

Soltani, S., Hammami, R., Cotter, P. D., Rebuffat, S., Said, L., Ben, E., et al. (2021). Bacteriocins as a new generation of antimicrobials: toxicity aspects and regulations. FEMS Microbiol. Rev. 45, 1-24. doi: 10.1093/femsre/fuaa039

Son, S. J., Park, M. R., Ryu, S. D., Maburutse, B. E., Oh, N. S., Park, J., et al. (2016). Short communication: In vivo screening platform for bacteriocins using Caenorhabditis elegans to control mastitis-causing pathogens. J. Dairy Sci. 99, 8614-8621. doi: 10.3168/jds.2016-11330
Taneja, N., and Sharma, M. (2019). Antimicrobial resistance in the environment: the Indian scenario. Indian J. Med. Res. 149, 119-128. doi: 10.4103/ijmr.IJMR_ 331_18

Taylor, P. W., Stapleton, P. D., and Paul Luzio, J. (2002). New ways to treat bacterial infections. Drug Discov. Today 7, 1086-1091. doi: 10.1016/S13596446(02)02498-4

Teschendorf, D., and Link, C. D. (2009). What have worm models told us about the mechanisms of neuronal dysfunction in human neurodegenerative diseases? Mol. Neurodegener. 4:38. doi: 10.1186/1750-1326-4-38

Theuretzbacher, U., Outterson, K., Engel, A., and Karlén, A. (2020). The global preclinical antibacterial pipeline. Nat. Rev. Microbiol. 18, 275-285. doi: 10.1038/ s41579-019-0288-0

Thomsen, T. T., Mojsoska, B., Cruz, J. C. S., Donadio, S., Jenssen, H., LøbnerOlesen, A., et al. (2016). The lantibiotic NAI-107 efficiently rescues Drosophila melanogaster from infection with methicillin-resistant Staphylococcus aureus USA300. Antimicrob. Agents Chemother. 60, 5427-5436. doi: 10.1128/AAC. 02965-15

Tissenbaum, H. A. (2015). Using C. elegans for aging research. Invertebr. Reprod. Dev. 59, 59-63. doi: 10.1080/07924259.2014.940470

Tossi, A., and Sandri, L. (2002). Molecular diversity in gene-encoded, cationic antimicrobial polypeptides. Curr. Pharm. Des. 8, 743-761. doi: 10.2174/ 1381612023395475

Tsai, C. J. Y., Loh, J. M. S., and Proft, T. (2016). Galleria mellonella infection models for the study of bacterial diseases and for antimicrobial drug testing. Virulence 7, 214-229. doi: 10.1080/21505594.2015.1135289

Tseng, C. C., Murni, L., Han, T. W., Arfiati, D., Shih, H. T., and Hu, S. Y. (2019). Molecular characterization and heterologous production of the Bacteriocin Peocin, a DNA Starvation/stationary phase protection protein, from Paenibacillus ehimensis NPUST1. Molecules 24:2516. doi: 10.3390/ molecules 24132516

Umu, ÖC. O., Bäuerl, C., Oostindjer, M., Pope, P. B., Hernández, P. E., PérezMartínez, G., et al. (2016). The potential of class II bacteriocins to modify gut microbiota to improve host health. PLoS One 11:e0164036. doi: 10.1371/journal. pone.0164036

Van Staden, A. D. P., Heunis, T., Smith, C., Deane, S., and Dicks, L. M. T. (2016). Efficacy of lantibiotic treatment of Staphylococcus aureus-induced skin infections, monitored by in vivo bioluminescent imaging. Antimicrob. Agents Chemother. 60, 3948-3955. doi: 10.1128/AAC.02938-15

Varas, M. A., Muñoz-Montecinos, C., Kallens, V., Simon, V., Allende, M. L., Marcoleta, A. E., et al. (2020). Exploiting Zebrafish Xenografts for Testing the in vivo antitumorigenic activity of Microcin E492 against human colorectal cancer cells. Front. Microbiol. 11:405. doi: 10.3389/fmicb.2020.0 0405

Wang, G., Yu, Y., Garcia-gutierrez, E., Jin, X., He, Y., Wang, L., et al. (2020). Lactobacillus acidophilus JCM 1132 strain and its mutant with different bacteriocin-producing behaviour have various in situ effects on the gut microbiota of healthy mice. Microorganisms 8:49. doi: 10.3390/ microorganisms 8010049

Wongsen, S., Werawatganon, D., and Tumwasorn, S. (2019). Lactobacillus plantarum B7 attenuates Salmonella typhimurium infection in mice: preclinical study in vitro and in vivo. Asian Biomed. 12, 211-218. doi: 10.1515/abm-20190022

World Health Organization (2017). WHO Publishes List of Bacteria for Which New Antibiotics are Urgently Needed. WHO Jt. News Release. Available online at: https:/www.who.int/news/item/27-02-2017-who-publishes-list-ofbacteria-for-which-new-antibiotics-are-urgently-needed (accessed January 17, 2020).

World Health Organization (2019a). 2019 Antibacterial Agents in Clinical Development: an Analysis of the Antibacterial Clinical Development Pipeline. WHO. Available online at: https://www.who.int/publications/i/ item/9789240000193 (accessed October 8, 2020).

World Health Organization (2019b). Antibacterial Agents in Preclinical Development: an Open Access Database. WHO. WHO/EMP/IAU/2019.12. Available online at: https://apps.who.int/iris/handle/10665/330290 (accessed March 22, 2021).

World Health Organization (2019c). New Report Calls for Urgent Action to Avert Antimicrobial Resistance Crisis. WHO Jt. News Release. Available online 
at: https://www.who.int/news/item/29-04-2019-new-report-calls-for-urgentaction-to-avert-antimicrobial-resistance-crisis (accessed January 14, 2020).

Wu, C. (2014). An important player in brine shrimp lethality bioassay: the solvent. J. Adv. Pharm. Technol. Res. 5, 57-58.

Yang, S.-C., Lin, C.-H., Sung, C. T., and Fang, J.-Y. (2014). Antibacterial activities of bacteriocins: application in foods and pharmaceuticals. Front. Microbiol. 5:241. doi: 10.3389/fmicb.2014.00241

Yi, C. C., Liu, C. H., Chuang, K. P., Chang, Y. T., and Hu, S. Y. (2019). A potential probiotic Chromobacterium aquaticum with bacteriocin-like activity enhances the expression of indicator genes associated with nutrient metabolism, growth performance and innate immunity against pathogen infections in zebrafish (Danio rerio). Fish Shellfish Immunol. 93, 124-134. doi: 10.1016/j.fsi.2019. 07.042

Yu, J., and Lu, Y. (2018). Artemia spp. Model-A well-established method for rapidly assessing the toxicity on an environmental perspective. Medical Research Archives 6, 1-15. doi: 10.18103/mra.v6i2.1700

Zasloff, M. (2002). Antimicrobial peptides of multicellular organisms. Nature 415, 389-395. doi: 10.1038/415389a
Zheng, S., and Sonomoto, K. (2018). Diversified transporters and pathways for bacteriocin secretion in gram-positive bacteria. Appl. Microbiol. Biotechnol. 102, 4243-4253. doi: 10.1007/s00253-018-8917-5

Zwierzyna, M., and Overington, J. P. (2017). Classification and analysis of a large collection of in vivo bioassay descriptions. PLoS Comput. Biol. 13:e1005641. doi: 10.1371/journal.pcbi.1005641

Conflict of Interest: The authors declare that the research was conducted in the absence of any commercial or financial relationships that could be construed as a potential conflict of interest.

Copyright (c) 2021 Benitez-Chao, León-Buitimea, Lerma-Escalera and MoronesRamirez. This is an open-access article distributed under the terms of the Creative Commons Attribution License (CC BY). The use, distribution or reproduction in other forums is permitted, provided the original author(s) and the copyright owner(s) are credited and that the original publication in this journal is cited, in accordance with accepted academic practice. No use, distribution or reproduction is permitted which does not comply with these terms. 